University of Rhode Island

DigitalCommons@URI

Open Access Master's Theses

2017

\title{
Agronomic Characteristics of Birdsfoot Trefoil (Lotus corniculatus L.) in the Northeast
}

Sarah Ferguson

University of Rhode Island, sarahmarferguson@gmail.com

Follow this and additional works at: https://digitalcommons.uri.edu/theses

\section{Recommended Citation}

Ferguson, Sarah, "Agronomic Characteristics of Birdsfoot Trefoil (Lotus corniculatus L.) in the Northeast" (2017). Open Access Master's Theses. Paper 976.

https://digitalcommons.uri.edu/theses/976

This Thesis is brought to you for free and open access by DigitalCommons@URI. It has been accepted for inclusion in Open Access Master's Theses by an authorized administrator of DigitalCommons@URI. For more information, please contact digitalcommons-group@uri.edu. 
AGRONOMIC CHARACTERISTICS OF BIRDSFOOT

TREFOIL (Lotus corniculatus L.) IN THE NORTHEAST

UNITED STATES

BY

SARAH FERGUSON

A THESIS SUBMITTED IN PARTIAL FULFILLMENT OF THE REQUIREMENTS FOR THE DEGREE OF

MASTER OF SCIENCE

IN

BIOLOGICAL AND ENVIRONMENTAL SCIENCES

UNIVERSITY OF RHODE ISLAND

2017 


\section{MASTER OF SCIENCE THESIS}

$\mathrm{OF}$

\section{SARAH FERGUSON}

\section{APPROVED:}

Thesis Committee:

$\begin{array}{ll}\text { Major Professor } & \text { Rebecca Nelson-Brown } \\ \text { Katherine Petersson } \\ \text { Bridget Ruemmele }\end{array}$

Nasser H. Zawia

DEAN OF THE GRADUATE SCHOOL

UNIVERSITY OF RHODE ISLAND

2017 


\begin{abstract}
Tanniferous forages, such as birdsfoot trefoil (Lotus corniculatus L.), are a potential control for the parasitic nematode Haemonchus contortus (barber pole worm). Gastrointestinal parasites cause huge economic loss in small ruminant production. Tanniferous forages have been shown to reduce counts of parasite eggs in feces of small ruminants. Currently the tanniferous forage Lespedza cuneate L. is used in the southern United States in control of gastrointestinal nematodes of small ruminants. It is not a viable option in the Northeast due to insufficient winter hardiness. Birdsfoot trefoil is adapted to the Northeast and may be a viable option as a tanniferous forage for small ruminant production if populations exist that combine anthelmintic efficacy with strong agronomic performance. To address this need, I collected data on the agricultural performance of 51 Plant Introductory (PI) accessions and six commercial cultivars.
\end{abstract}

In a three-year field study $(2013,2014$, and 2015) I evaluated growth habit, winter hardiness, pest resistance, uniformity and vigor for 57 populations. In 2015, I tested 19 PI accessions and six commercial cultivars for grazing tolerance, regrowth, and uniformity and vigor in a rotationally grazed pasture trial. Birdsfoot trefoil accessions were chosen for the studies based on condensed tannin contents reported in the literature. Tannin content and in vitro anthelmintic efficacy were compared to agronomic characteristics.

Growth habit was assessed using height/width ratios measured once each year. Winter hardiness was assessed as survival rate counted each spring. Birdsfoot trefoil is susceptible to potato leafhopper; damage by pests were visually evaluated. Quality 
was visually evaluated based on vigor and uniformity within each population. Vigor and uniformity was assessed yearly in the nursery plantings and immediately before each grazing event in the grazing trial. The eight-week grazing trial allowed for two grazing events for each of the nine replications. Grazing tolerance and regrowth were measured weekly for each replication throughout the eight weeks of grazing.

Accessions and cultivars showed a significant difference in 2013 and 2015 for potato leaf hopper damage $(\mathrm{P}<0.0001)$. There were also significant differences between accessions and cultivars for population uniformity and vigor scores and winter survival $(\mathrm{P}<0.0001)$. Winter survival ranged from 0 to $100 \%$ while uniformity scores of surviving plots ranged from 1 to 5 . A positive correlation was seen between plant survival and uniformity and vigor scores both in 2014 and 2015. PI306182, S3149, PI262530, PI262529, and PI255305 were high in vigor and uniformity scores averaged across 2014 and 2015; 2013 scores were not significantly different. 'Pardee', 'Leo', 'Empire' and 'Bull' were highest in uniformity and vigor scores for commercial cultivars averaged across 2014 and 2015. Growth habit was measured as height/width ratio and significant differences were seen in 2013 and 2015 but not in 2014. Cluster analysis divided the 51 accessions and six commercial cultivars into 6 clusters. Clusters did not correlate with tannin levels or efficacy but cluster means allowed for evaluation of agronomic characteristics of similar populations. All six commercial cultivars were clustered together in cluster $1(\mathrm{~N}=18)$ with favorable agronomic characteristic results. All the commercial cultivars also showed high anthelmintic efficacy, with the exception of 'Bruce'. PI193725, PI162425, PI180171, PI228286 and 
PI325379 are promising accessions that were included in cluster 1, ranking high across agronomic characteristics and in in vitro anthelmintic efficacy.

In the rotational grazing trial regrowth and combined uniformity and vigor differed significantly between populations for both grazing events. Plant survival varied widely with a low of 56.92\% for PI232098 and a high of 95.06\% for 'Empire'. After agronomic characteristics were assessed, anthelmintic efficacy and condensed tannin content were compared. In vitro efficacy and condensed tannin content showed no correlation. High efficacy was positively correlated with plant survival rates and uniformity and vigor. Regrowth was independent of anthelmintic efficacy.

This research identifies commercial cultivars and PI accessions with potential for anthelmintic efficacy against $H$. contortus and successful agronomic performance as a legume forage in the northeastern U.S. PI193725, PI180171, PI162425, PI228286, PI325379, 'Empire','Norcen','Bull', 'Pardee' and 'Leo' performed well agronomically and were efficacious in in vitro tests against $H$. contortus. 


\section{ACKNOWLEDGMENTS}

First off I would like to thank my advisor, Dr. Rebecca Brown for guidance during research and for countless edits on this thesis. I would also like to thank my committee members Dr. Katherine Petersson and Dr. Bridget Ruemmele.

Thank you to Tim Sherman and the agronomy farm crew for many hours of work on the field plots and to Nick Miniter and the Peckham Farm crew for care of the sheep that were used. Thank you to the students that set up the project before me.

I would like thank my husband, Joseph Fox for support throughout graduate school, it was not always easy! I would also like to thank Lorraine Perricone- Dazzo who inspired me to go to graduate school.

Finally funding for this project was provided by USDA OREI Grant No. 201251300-03654, thank you! 


\section{PREFACE}

The manuscript format outlined by the Graduate School at the University of Rhode Island will be utilized for the presentation of this thesis. Two manuscripts will make up the thesis that will be submitted to Genetic Resources and Crop Evolution.

The first manuscript is entitled "Evaluation of Potentially Anthelmintic Birdsfoot trefoil germplasm in the Northeast United States”

The second manuscript is entitled "Agronomic Evaluation of Potentially Anthelmintic Birdsfoot Trefoil Under Rotational Grazing in the Northeast United States" 


\section{TABLE OF CONTENTS}

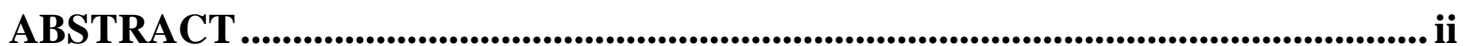

ACKNOWLEDGMENTS ...................................................................................................... v

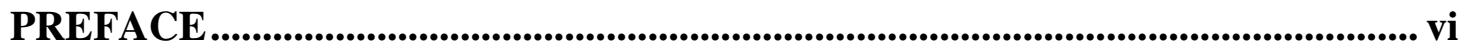

TABLE OF CONTENTS..................................................................................................... vii

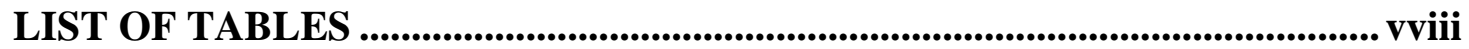

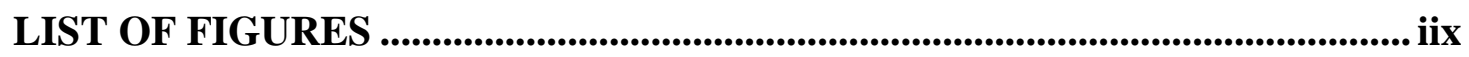

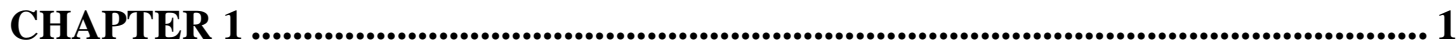

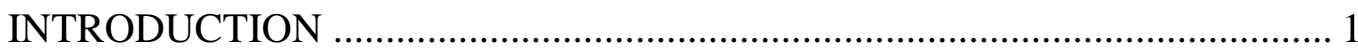

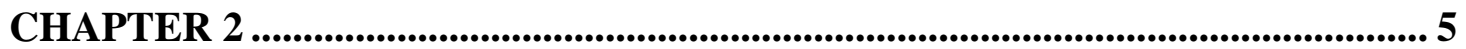

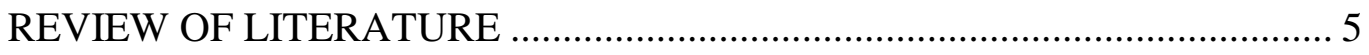

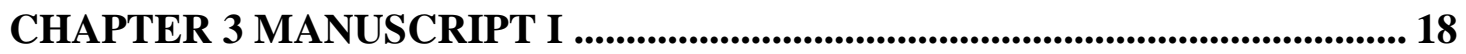

CHAPTER 4 MANUSCRIPT II ................................................................................... 42

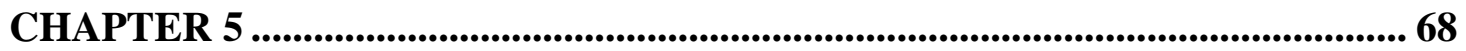

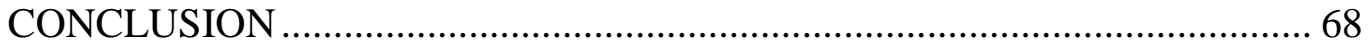

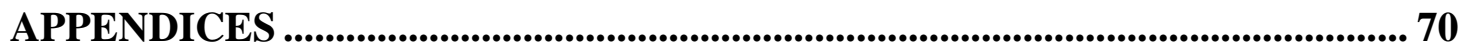

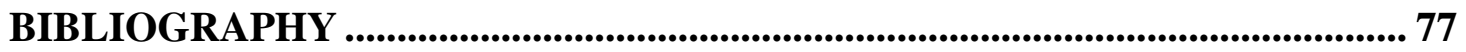




\section{LIST OF TABLES}

TABLE

PAGE

\section{MANUSCRIPT I}

Table 1. Populations with uniformity and vigor scores average at 4 or above........... 33

Table 2. Mean values for winter hardiness, leafhopper damage scores, uniformity and vigor scores and growth habit for the 6 clusters in cluster analysis......................... 36

\section{MANUSCRIPT II}

Table 1. 19 PI accessions and 6 commercial cultivars that were evaluated in the

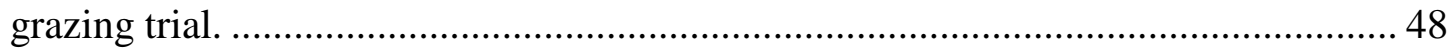

Table 2. Mowing and rotational grazing schedule for each of the nine replications .. 53 


\section{LIST OF FIGURES}

FIGURE

PAGE

\section{MANUSCRIPT I}

Figure 1. Examples of ratings given for leafhopper damage

Figure 2. Winter survival histogram for combined data from 2014 and 2015 out of 20

plants.

Figure 3. Growth habit scatterplot for years 2013 and 2015 31

Figure 4. Uniformity and vigor score histogram for 2014 and 2015. 32

Figure 5. Leafhopper damage scores histogram for 2013 and 2015 ..... 34

Figure 6. Dendrogram representing the cluster analysis of all 51 accessions and six commercial cultivars based on winter survival, leafhopper damage, growth habit and vigor and uniformity data collected in 2013, 2014 and 2015.

\section{MANUSCRIPT II}

Figure 1. Regrowth from grazing event 1 to week 4

Figure 2. Regrowth from grazing event 2 to week 8. 55

Figure 3. Post grazing event plant heights.

Figure 4. Scatterplot, Uniformity and Vigor Scores 1 vs. Uniformity and Vigor scores

2. 58

Figure 5. Average combined uniformity and vigor scores between PI accessions and commercial cultivars immediately before each grazing event. 59

Figure 6. Regression between plant survival and post grazing measurements. 60

Figure 7. Anthelmintic efficacy groups show significant differences between plant 
survival rates

Figure 8. Anthelmintic efficacy groups showed a significant difference in groups

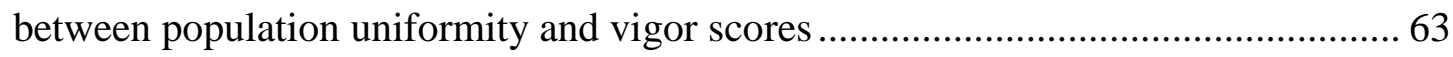




\section{CHAPTER 1}

\section{INTRODUCTION}

Despite an overall decline in sheep and goat farming in the United States the northeast region has seen an increase in production and demand in the past few decades (Jones, 2004). This is due to the increasing demand for fresh sheep and goat products from the local food movement. However, due to sporadic availability, imported meat from Australia and New Zealand supplements the U.S. market (Stanton, 2012). The factors limiting U.S. production are the ability to produce pasture and gastrointestinal nematode parasites. Climate, soil, and landscape are conducive to forage production including hay and pasture. Challenges include over grazing and underutilizing pastures (Jones, 2004).

Heamonchus contortus, a gastrointestinal nematode parasite, is responsible for the majority of economic loss to parasites in small ruminants (Hale, 2006). The spread of $H$. contortus takes place on the pasture. Helminth eggs are deposited in the feces of infected animals; the larvae are then ingested by animals while grazing. The susceptible animal becomes anemic and loses weight and death is likely (Santos et al., 2012). Heamonchus contortus larvae can live in a hypobiotic state in an animal throughout the winter and then resume development to the adult stage and lay eggs on pastures in the spring. With female adult nematodes depositing 5,000 to 10,000 eggs

per day H. contortus is detrimental to all sheep and goat producers (Leite-Browning, 
2006). H. contortus needs to be controlled to reduce economic loss in sheep production.

Currently synthetic anthelmintic treatments are used to control $H$. contortus (Hale, 2006). Organic producers cannot market meat as organic if they treat animals with synthetic anthelmintics, but have no other economically viable option (Haring et al., 2008). Routine use of synthetic anthelmintics leads to development of drug resistance in the $H$. contortus population; resistance has been documented to all three available drug classes (Fleming et al., 2006). Rotational grazing is routinely used to reduce infection, but it is labor intensive and requires large amounts of land. In the Northeast high prices for farm land and the rapid colonization of vacant land by woody species means that sufficient land is often not available (Colvin et al., 2008).

Forages containing condensed tannin (CT) (complexes of proanthocyanidin), a secondary plant metabolite, have the ability to suppress gastrointestinal parasites (Min and Hart, 2003). Condensed tannins are a heterogeneous series of monomers that vary in structure. The structure of condensed tannins are species specific and change throughout plant development (Haring et al., 2007). Condensed tannin content is highest in the leaves of forages and varying tannin structures allow astringency to vary (Waghorn, 2008). Tanniferous forages have shown a direct suppression of gastrointestinal parasites by disrupting the lifecycle of the nematode and preventing larvae from developing to the reproductive stage in in vitro tests (Molan, 1999). Birdsfoot trefoil (Lotus corniculatus L.) is a tanniferous forage that can be adapted to the Northeast's harsh climate and grows well on poorly drained and poorly aerated soils. Birdsfoot trefoil (BFT) incorporation in ruminants' diets is beneficial even in the 
absence of parasites, resulting in increased protein and amino acid intake without bloating, increased wool production and increased growth (Fleming et al., 2006). Birdsfoot trefoil production has further environmental benefits including reducing methane and ammonia emissions and converting atmospheric nitrogen to forms useable by plants and animals (MacAdam et al., 2006).

Birdsfoot trefoil has an established economic importance as a forage and for hay production. Breeding programs in the United States and Canada have been developing new varieties adapted to the Midwest with traits that will produce higher yield, but few varieties adapted to New England have been produced since the 1970s, and old varieties are generally unavailable (Grabber, 2014). None of the existing varieties have been developed specifically for use as anthelmintics. The agronomic challenges associated with using BFT include seed harvesting, stand establishment, and susceptability to root and crown rot. Once pasture is established BFT can be productive for many years with minimal input due to self seeding.

This research evaluated agronomic performance of BFT populations selected for potential as an anthelmintic forage in the northeastern U.S. Evaluation of data from field plantings determined agronomic performance based on growth habit, stand establishment, winter hardiness, grazing tolerance, regrowth speed and pest damage. Fifty-one accessions from the core subset at the National Plant Germplasm System and six commercially available varieties were evaluated. The results were cross referenced with the tannin profile and anthelmintic efficacy of each accession. The research was designed to test the following hypotheses. 
There will be significant difference in plant establishment and uniformity and vigor between populations. The different phenotypes in the numerous accessions of BFT will result in a wide range of adaptability to Northeast weather conditions (Escaray et al., 2012).

There will be significant differences between populations in winter survivability. A wide range of origins and adaptability affects the ability of the populations to survive the frost and harsh winters of the Northeast (Escaray et al., 2012).

The populations that show pest and disease resistance will have a higher growth rate. Pests and disease can limit the amount of biomass a variety can produce. Birdsfoot trefoil is particularly susceptible to root and crown rot and potato leaf hopper (Seaney and Hensen, 1970).

European type growth habit populations will show a faster regrowth after grazing than Empire type growth habit populations. Empire type BFT is more prostate in growth habit but are slower to establish and regrow after harvest or grazing than European type (Undersander et al.,1993). 


\section{CHAPTER 2}

\section{REVIEW OF LITERATURE}

\section{Birdsfoot Trefoil Agronomic Traits}

Birdsfoot trefoil (Lotus corniculatus L.) originated in the Mediterranean region and now occurs worldwide (Steiner et al., 2001). Reports from the late 1800s show birdsfoot trefoil (BFT) being cultivated in cattle pastures across Europe (Escaray et al., 2012). It is unknown how BFT was introduced to North America (Escaray et al., 2012). In 1957 it was estimated 770,000 acres in the U.S. were planted to BFT; ten years later acreage had more than doubled to 2 million acres (Saunders et al., 1969). Diaz et al. (2005) estimated that there were 3.43 million acres of the Lotus species sown for agronomic use in North America with $90 \%$ being BFT. It is clear that the economic value of BFT as a pasture forage and for hay production is well known. Birdsfoot trefoil is a well-adapted legume that can grow on poorly drained soil often unsuited to other forages (Undersander et al., 1993; Grabber et al., 2014). Due to genetic diversity and the easy adaptability of birdsfoot trefoil, many benefits can be expected from cross breeding varieties for specific traits (Escaray et al., 2012).

The National Plant Germplasm System (NPGS) has 627 accessions of BFT (USDA, 2016). There are 48 accessions of BFT in the core subset collection chosen from 21 different countries of origin including 12 cultivars, 2 germplasms, 27 wild or naturalized old world accessions, and 7 old world accessions with origin unknown. 
The NPGS core subset was divided into four genetic geographical diversity pools: Asia Minor $(n=8)$, European $(n=26)$, Mediterranean $(n=5)$ and North American $(\mathrm{n}=9)$ (Steiner et al., 2001). Steiner et al. (2001) used nine descriptors of each accession to describe each diversity pool including leaf size, pod weight, susceptibility to seed chalcid (Bruchophagus platypterus), herbage tannin content, flowering intensity, early flowering, seed globulin polypeptides, random amplified polymorphic DNA markers and flowering response index. The descriptors were analyzed with a cluster analysis and divided into interpretive groups for comparison.

Birdsfoot trefoil is currently a minor crop because of its low seedling vigor, slow establishment and poor persistence, particularly with the commonly grown North American varieties, such as 'Norcen' (Beuselinck, 1995, Waghorn et al., 1999). On well drained fertile land, BFT does not yield as well as alfalfa (Grabber et al., 2014). Birdsfoot trefoil plants only live for two to three years but reseed themselves, creating a population matrix with different developmental stages within a stand (Emery et al., 1999). A matrix stand increases tolerance of stresses such as drought that only affect seedlings, not established plants (Emery et al, 1999). Plantings managed to allow for reseeding require minimal maintenance for stand persistence. Birdsfoot trefoil requires a sunlight day length of 16 hours for optimal seed production; the Northeast's long summer days are ideal for a reseeding pasture (Emery et al., 1999). In years when BFT is allowed to reseed it can be hayed after seeds are dispersed (Ogle, 2009). Birdsfoot trefoil shows two distinct growth habits. The European type is more erect and adapted to haying, while the Empire type is more prostrate and adapted to grazing (Undersander et al., 1993). Although the European type is more vigorous after being 
harvested and regrows quickly the Empire type has thin stems and indeterminate growth making a better quality forage (Undersander et al., 1993).

A study using 12 different cultivars of BFT and 12 different cultivars of Lotus peduniculatus compared both species to monocultures and mixed plantings with non tanniferous grass (Haring et al., 2008). Plots were harvested seven times over three years to measure dry matter and weed competition and to quantify tannin content in plant tissue (Haring et al., 2008). It was found that the dry matter yield was greater from mixed plantings with Festuca pratensis than from monoculture for both Lotus species (Haring et al., 2008). It was also noted that weed composition was less in mixed swards compared to monocultures of BFT (Haring et al., 2008). In the second year of the study both forages produced more stem increasing dry matter production but decreasing the quality of the forage (Haring et al., 2008).

The Northeast can have harsh winters that a perennial forage must be able to survive. In this region winters can be highly variable and legumes such as BFT must be able to survive repeated freeze-thaw cycles without frost heaving. Grazing between September $1^{\text {st }}$ and the first killing frost will decrease winter survival of BFT (Undersander et al., 1993). Birdsfoot trefoil is considered to be winter hardy, but hardiness differs among populations (McGraw, 1989). Because varieties are from more than 20 different countries, winter hardiness is not always a strong point for each variety (Escaray, et al., 2012). Steiner et al. (2001) compiled minimum and maximum temperatures that could be tolerated for the four genetic diversity pools of the core subset collection, Asia Minor had a range of $-2.1^{\circ} \mathrm{C}$ to $20.7^{\circ} \mathrm{C}$, North American had the largest range of -7.1 to $22.1^{\circ} \mathrm{C}$, European had a range of 0.6 to $18.9^{\circ} \mathrm{C}$ and 
Mediterranean had a range of 7.6 to $23.7^{\circ} \mathrm{C}$. McGraw (1989) evaluated 48 different varieties from 21 different origins for winter hardiness over two years. Of the 48 varieties tested, 43 were foreign accessions; there was at least one accession from each country from which BFT accessions have been obtained. The study also included 2 germplasms from the US, and the cultivars 'Leo', 'Empire', and 'Viking'. 'Leo' and 'Empire', both North American cultivars, showed the best winter tolerance. North American varieties were also highly successful for herbage yield (McGraw, 1989). Winter tolerance, herbage yield and vigor were all positively correlated. There were also two accessions from Germany and Turkey that did well in winter tolerance, herbage yield and vigor (McGraw, 1989). McGraw (1989) and Steiner (2001) had similar results when looking at winter tolerance, four of the five most winter tolerant accessions and cultivars in McGraw's study fell into the North American geographic diversity group which Steiner found to tolerate lower temperatures.

Pests and disease can limit the amount of biomass a cultivar can produce. Birdsfoot trefoil is particularly susceptible to root and crown rot and potato leaf hopper (Seaney \& Hensen, 1970). 'Norcen', 'Empire' and 'Leo' have ranked high in many categories making them candidates for the Northeast but have low condensed tannin content and are still susceptible to root and crown rot (Carlson, 1983). It has also been noted that wilt has previously reduced stand persistance in the Northeast (MacAdam et al., 2006). Breeding programs of the 1990s in New York, Minnesota, Wisconsin and Washington released vareities with improved resistance to Fasarium wilt (Miller-Garvin, 2011). In 1999, Cornell University released 'Pardee' which is a cultivar that is rot and wilt resistant (Viands et al., 2004). Miller- Garvin (2011) tested 
six populations for resistance including, cultivar 'AC Langille', 81 - 82 Fusarium synthetic, Viking plus Schaaf bulk, 'WITT', 'Trevig' and MN from the breeding programs using 'Norcen' and 'Viking' commercial cultivars as controls. Using a randomised block design six vareities were inoculated with Fusarium oxysporum and another trial was not inoculated. Visual scores were made of each population. 'Viking' and 'Norcen' were found to have a higher percent of plants affected by Fusarium wilt (Miller - Garvin, 2011). All breeding populations showed resistance to the Fusarium wilt in inoculated and non inoculated tests through three cycles (Miller - Garvin, 2011). Potato leafhopper is a mid to late season pest that is slower to develop on BFT than alfalfa. Field to field leaf hopper damage is variable and a net sweep will identify presence before large scale hopper burn is visible. Leafhopper damage will cause general stunting in BFT stands (Undersander et. al, 1993).

\section{Medicinal Forages for Parasite Control}

Interest in tannin-containing forages is growing and is driving a renewal of interest in birdsfoot trefoil. Tannins are produced in plants as a secondary metabolite and are classified as hydrolysable tannins or condensed tannins (Min and Hart, 2003). Condensed tannins (CT) are more common and are complexes of oligomers and polymers of flavonoid units with a carbon - carbon bond that build up in cell vacuoles in many tissues of plants (Min and Hart, 2003). Condensed tannins are found at varying levels in many forages and can have positive and negative effects on animal health and production (Frutos et al., 2004). Tanniferous forages are particularly popular for use in small ruminants (sheep and goats). Tanniferous forages are low cost, highly nutritious and prevent bloat (Salem, 2010). Current tanniferous forages 
used for small ruminants include Lespedza cuneata in the southern U.S., sanfoin (Onobrychis viciifolia L.) in the western U.S., sulla (Hedysarum coronarium) in the Mediterranean basin and birdsfoot trefoil (Lotus corniculatus L.) in the northern US (MacAdam et al., 2003).

Gastrointestinal nematode parasites have caused widespread production losses in small ruminant production (Min and Hart, 2003). Moderate levels of condensed tanning containing forages have shown direct suppression of gastrointestinal parasites in in vitro tests by disrupting the lifecycle of the nematodes and preventing larvae from developing to the reproductive stage (Molan et al., 1999). The mechanism of the anthelmintic effect in vitro is still not clearly understood (Waghorn, 2008). Tannins also decrease the effects of gastrointestinal parasites indirectly by increasing available protein and amino acids, improving animals' ability to tolerate nematode infection (Haring, 2008). The CT can bind to protein and prevent degradation in the rumen, then dissociate in the abomasum when the $\mathrm{pH}$ falls below 3.5 allowing more amino acids to be absorbed in the small intestine (Waghorn, 2008; Frutos, 2004). The identity of the anthelmintic tannin(s) is unknown, so previous studies have correlated efficacy to total condensed tannin levels (Min and Hart, 2003; Grabber et al, 2014). However, the specific compounds within the condensed tannin pool vary by species, so the relationship between total CT and efficacy is specific to the species or cultivar. Min and Hart (2003) found that fecal egg counts in goats were reduced $50 \%$ when fed L. cuneata with condensed tannin levels ranging from 45 to 55 $\mathrm{g}$ of CT/kg of dry matter when compared to non-CT containing forages. When CT concentrations exceeded $55 \mathrm{~g}$ of CT/kg of dry matter or were below $45 \mathrm{~g}$ of CT/ $\mathrm{kg}$ of 
dry matter results varied. Forages high in CTs can have negative effects such as limiting growth and wool production, and lower palatability for grazing ruminants. High concentrations of $\mathrm{CT}$ in forage can result in free CT in the rumen that will react with enzymes secreted by bacteria and prevent rumen carbohydrate fermentation (Min and Hart, 2003).

It has been shown that lambs with high parasite burden will choose forages and plants high in condensed tannin when grazing freely while sheep with low parasite burden prefer plants low in condensed tannins. In the study by Lisonbee (2008) groups of 8 lambs with varying fecal egg counts were given different options of CT containing and non-CT containing forages. Lambs with high parasite burden were able to display self-medicating behavior by choosing the CT containing forage (Lisonbee, 2008).

Currently in the southern U.S. Lespedza cuneata is used as a medicinal forage to control $H$. contortus in small ruminants (Mechineni et al., 2014). L. cuneata is a moderate CT containing forage that is well adapted to the southern US. Studies have found that goats grazing on L. cuneata have lower fecal egg counts than goats only grazing on blue grass (Poa pratensis) (Mechineni, et al., 2014). Supplementing $L$. cuneata pellets in a grazing sheep's diet decreases worm burden and dependence on the use of synthetic anthelmintics (Gujja, et al., 2013). Lespedeza cuneata is not a viable forage for the Northeast because it cannot tolerate frost, however, birdsfoot trefoil is an adapted forage in the Northeast with varying levels of CTs. Birdsfoot trefoil has been in the forefront of tanniferous forage research in the Northeast because 
it has anthelmintic effects similar to Lespdeza and will reliably overwinter in the Northeast.

The accessions in the NPGS core subset of BFT have a large range of total condensed tannins ranging from $2.0 \mathrm{~m}$ eq. $\mathrm{g}^{-1}$ to $98.0 \mathrm{~m}$ eq. $\mathrm{g}^{-1}$ (Steiner et. al, 2001). Steiner et. al (2001) found that the North American and Asia Minor geographic diversity pools had the lowest herbage tannin content $\left(2.0\right.$ to $9.0 \mathrm{~m} \mathrm{eq.} \mathrm{g}^{-1}$, mean $=4.0$ m eq. $\mathrm{g}^{-1}$ ) while the Mediterranean diversity pool had the highest tannin content (53.0 to $98.0 \mathrm{~m}$ eq. $\mathrm{g}^{-1}$, mean $=71.3 \mathrm{~m}$ eq. $\left.\mathrm{g}^{-1}\right)$. Grabber et al. $(2014)$ evaluated 14 cultivars over two years in three different environments (location) including, 'Au Dewey', 'Pardee', 'Georgia', 'Grasslands Goldie', 'Bokor', 'Oberhaunstadter', 'Rodeo', 'Norcen', 'Viking', 'Exact', 'NC-83' and 'NC-83HT'. Condensed tannins were estimated spectrophotometrically in each cultivar and ranged from $14.0 \mathrm{~g} / \mathrm{kg}^{-1}$ in 'Norcen' to $31.6 \mathrm{~g} / \mathrm{kg}^{-1}$ in 'Rodeo' (Grabber et al., 2014). Grabber et al. (2014) concluded that environment and cultivar equally influenced CT concentrations. Condensed tannin concentrations were found to vary depending on maturity of the plant and the environment but relative rankings among cultivars remained consistent; 'Norcen' always remained lowest in CT levels (Grabber et al., 2014). Roberts et al. (1993) studied tannin content in 97 accessions of BFT from the USDA Northeast Regional Plant Introduction Station in Geneva, New York. The study was conducted at two locations in Missouri with three harvest dates for each location over one growing season (May- August). Accessions were found to have a wide range of condensed tannin concentrations based on harvest date and location. Tannin content 
fluctuated more in high- tannin accessions than low- tannin accessions (Roberts et al., 1993).

A United Kingdom study found that lambs grazing on BFT, specifically the cultivar 'Leo', had lower fecal egg counts after 7 days than those grazing on chicory or white clover, neither of which contain condensed tannins (Marley, 2003). At the end of the study slaughtered lambs that had grazed BFT had fewer adult helminth parasites in the abomasum than did lambs that had grazed on the other two forages (Marley, 2003). The decreases in fecal egg counts and helminth parasites are correlated to an increase in wool production, daily weight gains and increase reproductive ability (Athanasiadou, 2001).

\section{Grazing Trials}

Grazing trials are needed in agronomic performance studies of forages to identify accessions that will be able to tolerate trampling and defoliation and to determine the amount of rest time needed in between grazing events (Sollenberger, 2015). Grazing trial results may be very region specific depending on characteristics being tested (Sollenberger, 2015). Time and space limitations make grazing trials challenging. However, short term, small scale studies can predict long term outcomes (Sollenberger, 2015).

Birdsfoot trefoil, once established, is persistent under grazing when grown in mixtures with grass (MacAdam et al., 2006). Pastures must be maintained as overgrazing will decrease regrowth. Heavy grazing is not recommended because BFT keeps energy reserves in the top growth as opposed to the roots (Undersander et al., 1993). The height of $7 \mathrm{~cm}$ will allow for regrowth to occur without damaging the BFT. 
Overgrazing of BFT will prevent regrowth and promote winter injury (Undersander, et al., 1993).

An eight-year study to evaluate birdsfoot trefoil pasture took place in Iowa from 1956 - 1963. The study compared BFT to white clover and Kentucky bluegrass (Poa pretensis L.) for long term persistency, yield, and suitability for grazing. Wedin (1967) set up three treatment pastures, replicated three times, that were each grazed continuously by three cows with calves for each grazing season. Tester cows were weighed for each treatment. Cages placed in each pasture allowed for dry matter weight and botanical composition estimations. Forage yields were found to be higher for BFT pasture (Wedin, 1967). Weed composition was also higher in the BFT pasture (Wedin, 1967). Over the eight year period BFT pasture was also most productive in beef production (Wedin, 1967).

Davis and Bell (1957) researched a BFT and Kentucky bluegrass (Poa pretensis L.) mixture for pasture in comparison with a Ladino clover (Trifolium repens L.) and Kentucky bluegrass mixture over a three year grazing study. They measured lamb weight gains, total digestible nutrients and carrying capacity. There were sixteen paddocks of pasture divided between the BFT bluegrass mixture and the Ladino clover blugrass mixture, 4 being continuously grazed and the remaining being rotationally grazed. Rotationally grazed paddocks were grazed for 10 to 16 days and rested for 24 to 30 days. In the establishment year the lambs on the Ladino clover bluegrass mixture gained more weight, the forage contained more total digestible nutrients and the pasture had a higher carrying capacity than the BFT bluegrass mixture. However, for the following two years the BFT pasture excelled in all three criteria (Davis and Bell, 
1957). The Ladino clover bluegrass mixture stand was dramatically reduced in the last two years due to drought, BFT pasture under continuous grazing was also reduced due to overuse but the rotationally grazed BFT stands persisted the three years (Davis and Bell, 1957).

Many birdsfoot trefoil grazing trials in the literature focus on the animal outcome. Often the study will only use one or two BFT cultivars and may not even specify which cultivar is being used. Studies have shown a positive outcome of more wool production, higher weight gains, and lower fecal egg counts in animals fed BFT. Studies that look at BFT tannin content and the medicinal advantages of grazing on BFT do not include agronomic performance of the BFT accessions used. Regional variety trials compare performance of different BFT cultivars, but these trails do not subject the cultivars to grazing. As a result, little is known about the suitability of BFT cultivars and accessions for rotational grazing.

Grazing variety trials have been done on other species that can be used as examples for birdsfoot trefoil. One hundred and forty-two red clover accessions were evaluated for forage persistence during a rotational grazing trial using cattle that lasted 3.5 years in New Zealand (Ford, 2011). The study measured persistence and regrowth based on ratings of all 142 accessions 15 times over the course of the study (Ford, 2011). Each population was given an establishment score; a rating of 1 indicated lowest establishment and 10 was highest establishment. Growth rate ranges increased over the four-year study to show significant differences in species' persistence under cattle grazing. Upon termination of the study plant survival ranged from $4 \%$ to $60 \%$ showing significant differences in grazing tolerance (Ford, 2011). 
A study in Wisconsin of different cool season perennial grasses under an intensive grazing system collected data on ninety-one different varieties on three different dairy farms. The study specifically looked at available bulk density, winter hardiness and ground cover of perennial grasses (Casler, 2013). Each paddock was rotationally grazed five to six times over a two year period with measurements taken before and after each grazing session (Casler, 2013). The measurements of each characteristic presented significance among species and within species (Casler, 2013).

The literature shows the potential for BFT as a legume forage in the Northeast region and a potential anthelmintic treatment for gastrointestinal nematodes in small ruminants. There is a gap in the literature for variety trials of BFT agronomic performance in the northeastern US under rotational grazing. This study aimed to fill the gap by collecting agronomic performance data under rotational grazing and cross referencing it with anthelmintic efficacy data. The objective was to identify potential BFT accessions that would be a viable forage in the northeast region and act as an anthelmintic treatment against $H$. contortus. 


\title{
MANUSCRIPT I
}

“EVALUATION OF POTENTIALLY ANTHELMINTIC BIRDSFOOT TREFOIL GERMPLASM IN THE NORTHEAST U.S.”

\author{
BY \\ Sarah Ferguson ${ }^{1}$, Rebecca Brown ${ }^{2}$, Katherine Petersson ${ }^{3}$, and Carly Barone ${ }^{4}$ \\ Will be submitted to Crop Genetics and Evolution
}

${ }^{1}$ Master of Science Candidate, Department of Plant Sciences and Entomology, University of Rhode Island, Kingston, R.I. Email: Sarahmarferguson@gmail.com

${ }^{2}$ Associate Professor of Plant Sciences, Department of Plant Sciences and Entomology, University of Rhode Island, Kingston, R.I. Email: brownreb@uri.edu

${ }^{3}$ Associate Professor of Animal Sciences, Department of Fisheries, Animal and Veterinary Sciences, University of Rhode Island, Kingston, R.I. Email:

Kpetersson@uri.edu

${ }^{4}$ Docteral of Science Candidate, Department of Fisheries, Animal and Veterinary Sciences, University of Rhode Island, Kingston, R.I. Email:

Carly_Barone@myuri.edu 


\title{
CHAPTER 3
}

\section{EVALUATION OF POTENTIALLY ANTHELMINTIC BIRDSFOOT TREFOIL GERMPLASM IN THE NORTHEAST U.S.}

\begin{abstract}
Birdsfoot trefoil (Lotus corniculatus) is a tanniferous legume forage with the potential to control gastrointestinal parasitic nematodes in small ruminants. The objective of this research was to evaluate birdsfoot trefoil populations, selected for condensed tannin content, for strong agronomic performance as a forage in the northeastern U.S. Three replications in a randomized block design of field plantings were evaluated for potato leafhopper damage, winter survival, uniformity and vigor, and growth habit in 2013, 2014, and 2015. Analysis of variance and Tukey's HSD tests were used for mean comparisons. Accessions and cultivars showed significant difference in 2013 and 2015 for potato leafhopper damage $(\mathrm{P}<0.0001)$. Leafhopper damage was more severe in 2015. There was also a significant difference between accessions for population vigor, uniformity, and winter survival $(\mathrm{P}<0.0001)$. A positive correlation was seen between plant survival and uniformity and vigor scores both in 2014 and 2015. Growth habit was measured using the height/width ratio and significant differences were seen in 2013 and 2015 but not 2014. Cluster analysis divided the 51 accessions and six commercial cultivars into 6 clusters $\left(\mathrm{R}^{2}=0.90\right)$ based on average Euclidean distance. Clusters of like performing accessions were identified using winter survival, leafhopper damage, growth habit, population uniformity and vigor data. Clusters did not correlate with tannin levels or in vitro anthelmintic efficacy but
\end{abstract}


cluster means allowed for evaluation of agronomic characteristics of similar populations. All six commercial cultivars were clustered together $(\mathrm{N}=18)$ with favorable agronomic characteristics and high anthelmintic efficacy, with the exception of 'Bruce'. PI193725, PI162425, PI180171, PI228286 and PI325379 are promising accessions that were included in the same cluster ranking high across agronomic characteristics and for in vitro anthelmintic efficacy.

Keywords: variety trial, Lotus corniculatus L., tanniferous forage 


\section{Introduction:}

Small ruminant production worldwide is negatively affected by the spread of gastrointestinal parasites, specifically the barber pole worm (Haemonchus contortus) (Min and Hart, 2003). Resistance of parasites to currently used commercial anthelmintics is wide spread (Fleming, et al., 2006). Tanniferous forages containing moderate amounts of condensed tannins (CTs) have been shown to suppress the symptoms of $H$. contortus infection in small ruminants (Min and Hart, 2003). Condensed tannin containing forages have been shown to suppress gastrointestinal parasites by disrupting the lifecycle of the nematode and preventing larvae from developing to the reproductive stage in in vitro tests (Molan et al., 1999). Tannins are produced in plants as a secondary metabolite and are classified as hydrolysable tannins or condensed tannins (Min and Hart, 2003). Condensed tannins (CT) are more common and are complexes of oligomers and polymers of flavonoid units with a carbon - carbon bond that build up in cell vacuoles in many tissues of plants (Min and Hart, 2003). Varying amounts of condensed tannins in different varieties of forages can have differing results; the identity of the anthelmintic tannins are unknown, so previous studies have correlated efficacy to total condensed tannin levels (Min and Hart, 2003; Grabber et al., 2014). However, forages high in condensed tannins (above $55 \mathrm{~g} \mathrm{CT} / \mathrm{kg}$ of dry matter) are less palatable and can have negative effects on grazing ruminants such as limiting growth and wool production (Min and Hart, 2003).

Birdsfoot trefoil (Lotus corniculatus L.) is a tanniferous legume forage that is adapted to the Northeast and has been shown to decrease nematode burden as 
measured by fecal egg counts in small ruminants (Waghorn, 2008). Birdsfoot trefoil (BFT) populations vary in condensed tannin content. North American varieties are generally low in CTs compared to Mediterranean and European varieties (Grabber et al., 2014; Steiner et al., 2001). Birdsfoot trefoil has potential as a small ruminant forage in the northeastern U.S. because of the improved production seen in small ruminants grazing on BFT. Birdsfoot trefoil is drought tolerant and can flourish on poorly drained acidic soils; it also grows well on well drained soils although when compared to alfalfa (Medicago sativa L.), alfalfa had a higher yield (Grabber et al., 2014). The challenges that limit use of BFT are poor stand establishment and low seedling vigor (Seaney and Hensen, 1970). Pests and disease can limit the amount of biomass a variety can produce. Birdsfoot trefoil is particularly susceptible to root and crown rot and potato leafhopper (Empoasca fabae) (Seaney and Hensen, 1970). Once established, BFT is a low maintenance forage due to self-seeding with individual plants living for two to three years (Emery et al., 1999).

Birdsfoot trefoil originated in the Mediterranean and has since been adapted to many climates worldwide. As varieties are from more than 20 different countries, winter hardiness can be variable (Escaray, et al., 2012). In the northeast region winters can be highly variable and legumes such as BFT must be able to survive repeated freeze-thaw cycles without frost heaving.

A previous study by Grabber et. al. (2014) evaluated fourteen cultivars of BFT in Wisconsin, Utah, Michigan and West Virginia for yield, morphological characteristics and chemical composition originating from European and Mediterranean linage. The results concluded that environment influenced condensed 
tannin concentration and dry matter yield. Further evaluation was called for in eastern states where poor disease resistance, persistence and long term yield have had an impact of BFT production. A critical need exists to evaluate BFT populations in the North East United States as a forage to improve sheep production.

The main objective of this research was to evaluate BFT populations selected for condensed tannin content for strong agronomic performance as a forage in the northeastern U.S. Evaluation of data from field plantings determined the agronomic performance based on growth habit, uniformity and vigor, winter hardiness, and pest tolerance.

\section{Material and Methods}

\section{Site Description:}

The experimental plot was established in Summer 2013 at University of Rhode Island's Greene H. Gardiner Crop Science Field Laboratory in Kingston, RI. The soil in this part of the farm is Bridgehampton silt loam with a 0-3\% slope (Web Soil Survey staff, 2016). During the three years of data collection the temperature ranged from $-25.2^{\circ} \mathrm{C}$ to $33.3^{\circ} \mathrm{C}$ (NOAA, 2016). Precipitation varied for each growing season and each winter. In the 2013 growing season from May until September there was $728.7 \mathrm{~mm}$ of rainfall. During the 2014 growing season there was $331.5 \mathrm{~mm}$ of rainfall. There was $322.6 \mathrm{~mm}$ of rainfall in the 2015 growing season. Winter precipitation for from October 2013 to April 2014 was $452.2 \mathrm{~mm}$ and precipitation for winter 2014 to 2015 was $728.7 \mathrm{~mm}$ (NOAA, 2016).

This project included 6 commercial cultivars commonly grown in the U.S. and Canada and 51 PI accessions from the National Germplasm System (Pullman, 
WA) and university breeding programs (University of Minnesota, Minneapolis, MN; Cornell University, Ithaca, NY) from varying origins. These accessions were chosen based on the condensed tannin content. Condensed tannin content of the accessions in the study ranged from 2 to $105 \mathrm{~g}^{*} \mathrm{~kg}^{1} * \mathrm{DM}$ (Roberts et al., 1993; Grabber et al., 2014; GRIN database).

\section{Plant Production:}

The BFT plants were grown from seed obtained from the National Plant Germplasm System (NPGS) (Pullman, WA) and directly from breeders (Minneapolis, MN; Ithaca, NY). The seeds were started using Organic Mechanics mix (The Organic Mechanics Soil Company, Chester County, PA) in trays placed in a greenhouse under mist in late January 2012 . The greenhouse was kept between $18.3^{\circ} \mathrm{C}$ and $22.2^{\circ} \mathrm{C}$. Once the seedlings had two true leaves they were transplanted to 38-count plug trays, and then in mid-March were transplanted to $7.5 \mathrm{~cm}$ square pots. The seedlings were treated with organic liquid fertilizer (Neptune's Harvest, Gloucester, MA; Miracle Gro, Marysville, $\mathrm{OH}$ ) weekly and watered daily. Two different liquid fertilizers were used, the first, Miracle Gro Organic, was an 8-0-0 NPK ratio diluted to 1oz per 2 gallons of water and the second, Neptune's Harvest, was a seaweed based extract with an analysis of $0.17 \%$ nitrogen and $1.42 \%$ potassium which was diluted to $1 \mathrm{oz}$ per 2 gallons of water. The BFT plants were hardened off outside in early May before being transplanted to field plots.

\section{Experimental Plot Establishment:}

In September 2012, the field was seeded with chewings fescue (Festuca rubra subsp. commutate). In May 2013, the BFT was transplanted into the established stand 
of chewings fescue. The field was laid out in a randomized plot design with three replications. Each population had twenty plants spaced $30.5 \mathrm{~cm}$ apart within rows and $76 \mathrm{~cm}$ between rows. Holes with a diameter of $7.5 \mathrm{~cm}$ and a depth of $15 \mathrm{~cm}$ were dug using an auger. Transplants were placed in the holes by hand, and holes were backfilled with Organic Mechanics mix inoculated with Rhizobium leguminosarum biovar vicege (N-Dure INTX Microbials LLC, Kentland, IN). Each plant was watered immediately after planting. The commercial cultivars and PI421026 were added to the randomized block design in early June 2014, along with additional plants for some populations with poor germination in 2013.

Plants to replace ones that died in 2013 were vegetatively propagated using cuttings collected from the field nursery in September 2013. Vegetative propagation was done using the two-node stem cut method (Seany and Hansen 1970) into 72 count plug trays filled with Organic Mechanics mix and placed in the greenhouse under a mist. The misters were on twice a day, from 8:00am until 8:20am and again from 4:30pm until 4:50pm. The greenhouse was kept between $18.3^{\circ} \mathrm{C}$ and $22.2^{\circ} \mathrm{C}$. Once the cuttings were rooted they were transplanted to 38-count plug trays, and then in late November were transplanted to $7.5 \mathrm{~cm}$ square pots. The cuttings were treated with organic liquid fertilizer (Neptune's Harvest, Gloucester, MA; Miracle Grow, Marysville, $\mathrm{OH}$ ) weekly and watered daily. Cuttings were transplanted into the nursery in early July 2014. Additional plants to replace plots with severe winter kill were vegetatively propagated in early May 2014 following the same procedure and transplanted into the nursery in August 2014.

\section{Experimental Plot Maintenance:}


The study area was fertilized in late June of 2013 and in early May in 2014 and early May in 2015. Nutrients were applied based on soil test results, balancing the needs of the chewings fescue with those of the birdsfoot trefoil. Organic granular fertilizers were spread with the Scotts 3000 drop rotary spreader (The Scotts Company, Marysville, OH). In 2013, $7 \mathrm{~kg} / \mathrm{ha}$ nitrogen, $26.9 \mathrm{~kg} / \mathrm{ha}$ of phosphorous, $32.5 \mathrm{~kg} / \mathrm{ha}$ potassium, $9.1 \mathrm{~kg} / \mathrm{ha}$ sulfur and $0.8 \mathrm{~kg} / \mathrm{ha}$ boron were applied. In 2014, 759 $\mathrm{kg} / \mathrm{ha}$ of lime and $190 \mathrm{~kg} / \mathrm{ha}$ of sulfate of potash $(80 \mathrm{~kg} / \mathrm{ha}$ of potassium and $34.2 \mathrm{~kg} / \mathrm{ha}$ sulfate) were applied. In 2015, $33 \mathrm{~kg} / \mathrm{ha}$ of nitrogen, $50 \mathrm{~kg} / \mathrm{ha}$ of phosphorous, and 99 $\mathrm{kg} / \mathrm{ha}$ of potassium were spread. Weeds were controlled by mowing in between rows to a height of $7.5 \mathrm{~cm}$ weekly, and hand-pulling within rows. At the beginning of spring 2014 plants were mowed to $12.5 \mathrm{~cm}$ in height. In late July/early August 2014 each accession was measured for height and width and then hand clipped to approximately $12.5 \mathrm{~cm}$. In late August 2015 plants were mowed to $12.5 \mathrm{~cm}$ in height to control leafhopper (Empoasca fabae) damage.

\section{Data Collection:}

\section{Winter Hardiness:}

Birdsfoot trefoil is considered to be winter hardy, but hardiness differs among populations. To evaluate winter hardiness, the number of surviving plants in each population were counted in the early spring in 2014 and 2015.

\section{Growth Habit:}

Three plants at random from each plot, excluding plants at the ends of the plot, were measured for height and width. To measure the height of a plant a meter stick was placed in the center of the crown and branch length was measured to the tip of the 
highest branch in centimeters. To measure the width of a plant the meter stick was placed on top of the plant and measured from tip of the longest branch to tip of the longest branch on the other side in centimeters. The height was divided by the width to give a ratio for each plant. Three plants from each plot were measured each year from 2013 - 2015. The measurements for 2013 were taken June 18 - 25 and August 5 -12. In 2014 measurements were taken June 15 - 17 and August 18 - 20. In 2015 measurements were taken June 1 - 3 and August 3 - 7 .

Uniformity and Vigor:

Combined uniformity and vigor were visually evaluated each year with a score of 1 indicating variable, weak looking plants and a score of 5 indicating very similar and strong looking plants that filled in the plot with an abundance of herbage. A score of 3 was a population with greater than $50 \%$ of the plants showing good growth and solid establishment. Uniformity and vigor were evaluated independent of plant survival. Plants were evaluated in comparison with other plants present. This method was adapted from McGraw's (1989) methods for evaluating growth habit of BFT.

\section{Leafhopper Damage:}

Leafhopper damage was evaluated in 2013 and 2015. Each population was visually rated from 1 to $9 ; 1$ being at least $50 \%$ of leaves suffering from leafhopper burn and 9 being no visible signs of leafhopper damage. This method was adapted from Elden and McCaslin's (1997) method of evaluating leafhopper damage on alfalfa (Medicago sativa L.).

Figure 1: Examples of ratings given for leafhopper damage.

A score of 1 with at least $50 \%$

of leaves suffering from
A score of 6 with moderate visible damage not reaching
A score of 9 with no visible signs of leafhopper damage. 


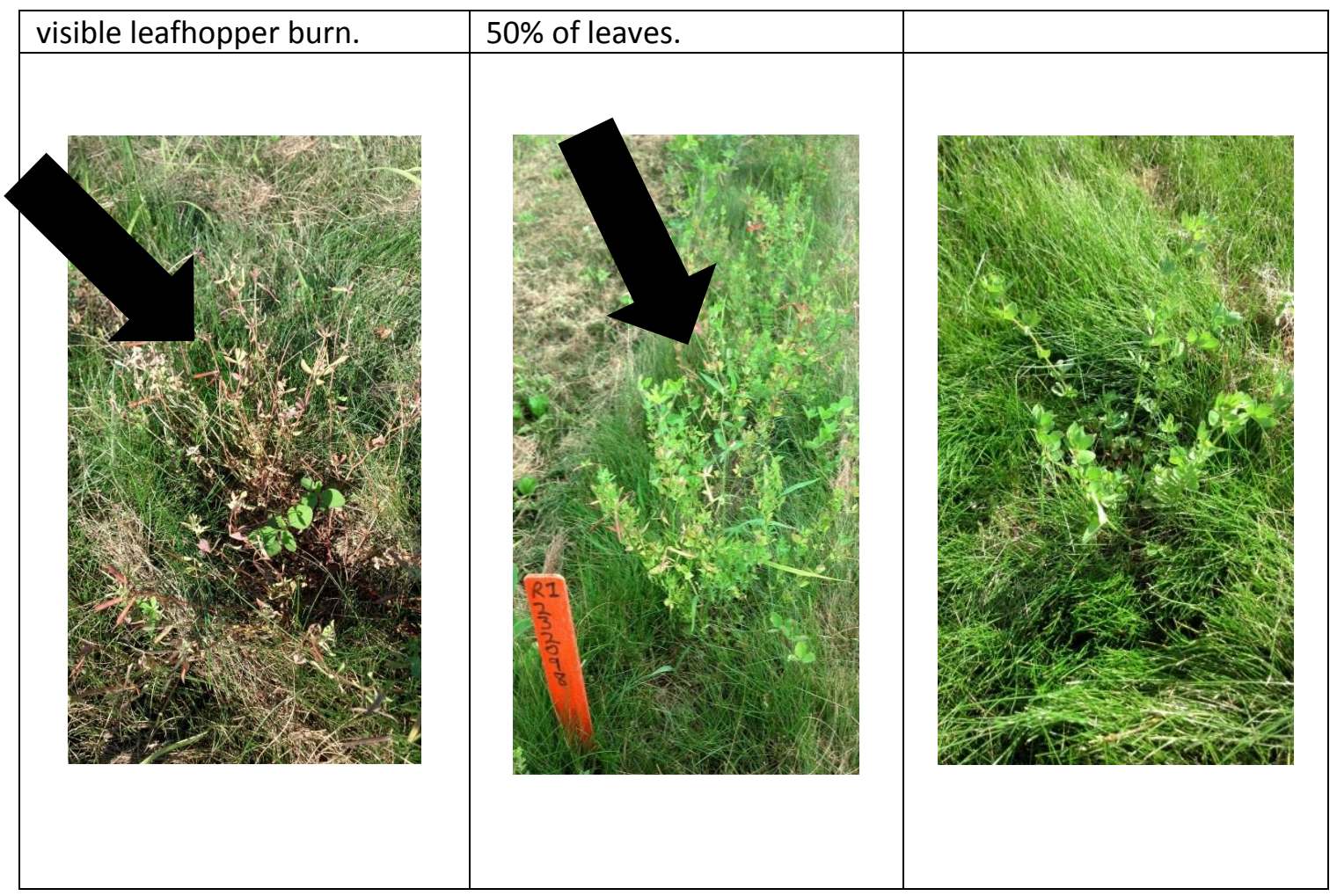

\section{Statistical Analysis:}

The nursery was laid out in a randomized block design with three replications of 51 PI accessions and six commercial cultivars. Statistical analysis was done using cluster analysis in JMP statistical discovery software (Statistical Analysis System Inst., Cary, NC); a resulting dendrogram was used to identify like performing populations. Analysis of variance tests were done to test for significance between populations and between years. A P-value $(\mathrm{P})$ of 0.05 or below was considered significant. Tukey's HSD test was used for means comparison when differences were significant to identify top performing accessions. Regression tests were used to determine correlations between agronomic characteristics. In vitro anthelmintic efficacy and condensed tannin concentrations were compared agronomic data to 
determine agronomic characteristic independence from tannin concentrations and in vitro efficacy.

\section{Results and Discussion:}

There were significant differences between populations $(\mathrm{P}<0.0001)$ for winter hardiness in 2014 and 2015 combined (HSD: 9.1). Winter survival averages across the three replications ranged from 20 plants to 0 plants (Figure 2). From November 2013 to February 2014 temperatures ranged from -21.8 to $19.3^{\circ} \mathrm{C}$ with a total of $215.7 \mathrm{~mm}$ of snow. From November 2014 to February 2015 the temperature ranged from -25.2 to $19.1^{\circ} \mathrm{C}$ with a total of $452.4 \mathrm{~mm}$ of snow. Winter survival was not significantly different between years. There were five populations, PI228286, PI227849, PI246735, PI383687 and PI383689, that showed very different plant survival in 2014 and 2015. These five accessions had lower plant survival in 2015, which could be because of the higher amount of snow in the 2014-2015 winter. The most winter hardy populations were PI233807, PI226796, PI255305, PI251146, and PI255302 all of which averaged 19.50 to 20.0 surviving plants. These populations originated from Canada, the United States, France and Italy. The three populations with the lowest plant survival were PI273937, PI273938 and PI260268. All are wild or uncertain types originating from Ethiopia; survival ranged from 0.17 to 1.3 plants. These were also the three populations with the highest condensed tannin levels. The accessions with the highest condensed tannin could have the lowest winter survival rates because there is a trade off in plant physiology between producing secondary metabolites and producing foliage growth (Zandt, 2007). Birdsfoot trefoil keeps energy reserves in its top growth as opposed to its' roots making foliage growth imperative to winter survival 
(Undersander et al., 1993). These results are consistent with Steiner et al. (2001), who found that the North American, European and Asia Minor diversity groups could tolerate significantly colder temperatures than the Mediterranean diversity group. The six commercial cultivars and PI421026 were only evaluated in 2015; they all had excellent survival.

The results showed that there were plots that had $100 \%$ plant survival and many replications were consistent both years and across replications. Winter hardiness data shows that there are potential birdsfoot trefoil accessions that could survive the harsh winters of the Northeast.

Figure 2: Winter survival histogram for combined data from 2014 and 2015 out of 20 plants. Plants that were winter killed in 2013 -2014 were replaced in 2014. Commercial cultivars and PI 421026 were added in 2014.

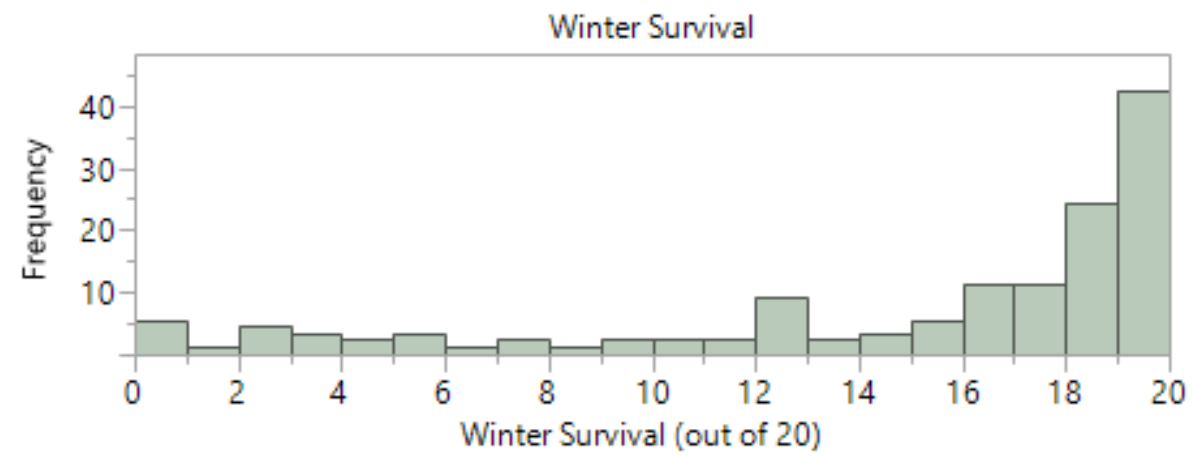

Birdsfoot trefoil has two different growth habits, European, which is erect and optimal for haying and Empire which is prostrate and ideal for grazing (Undersander, 1993). The European type plants are vigorous and regrow quickly after being harvested. The Empire type plants have thin stems and indeterminate growth which produce a better-quality forage (Undersander, 1993). Birdsfoot trefoil with grass mixtures is persistent under grazing once established but heavy grazing will decrease 
regrowth (Undersander, 1993). Regrowth time should be allowed prior to winter to promote winter survival (Undersander, 1993).

Height/width ratio is a measure of growth habit. Height/width ratio data were collected in 2013, 2014, and 2015 with significant differences between populations only occurring in $2013(\mathrm{P}<0.0001)$ and $2015(\mathrm{P}=0.0399)$ (Figure 3). Significant difference between 2013 and 2015 could be due to varied growth rates, as 2013 was the year of establishment. Weather differences could also explain the varied growth habits. In 2013 temperature ranged from 0.1 to $33.3^{\circ} \mathrm{C}$ with $618.7 \mathrm{~mm}$ of rainfall (NOAA, 2016). In 2015 the temperature range was similar but there was only 322.6 mm of rainfall (NOAA, 2016). Growth habits in 2013 ranged from 2.78 for PI310483 to 0.57 for PI325279, 2015 growth habits ranged from 2.47 for PI273938 to 0.68 for PI246730. Although growth habits were in a similar range populations differed between years and size of plants also differed (Figure 3). There were five populations that consistently expressed a flatter growth habit which is better for grazing, PI246730, PI240753, PI306182, PI251143 and PI325379. There were also two populations that consistentlyexpressed an erect growth habit, PI260268 and PI273938.

Figure 3: Height vs. Width scatterplot for 2013 and 2015. 2014 height and width data were not significant (not included). The triangle labels represent accessions that had consistent growth habits for 2013 and 2015. 


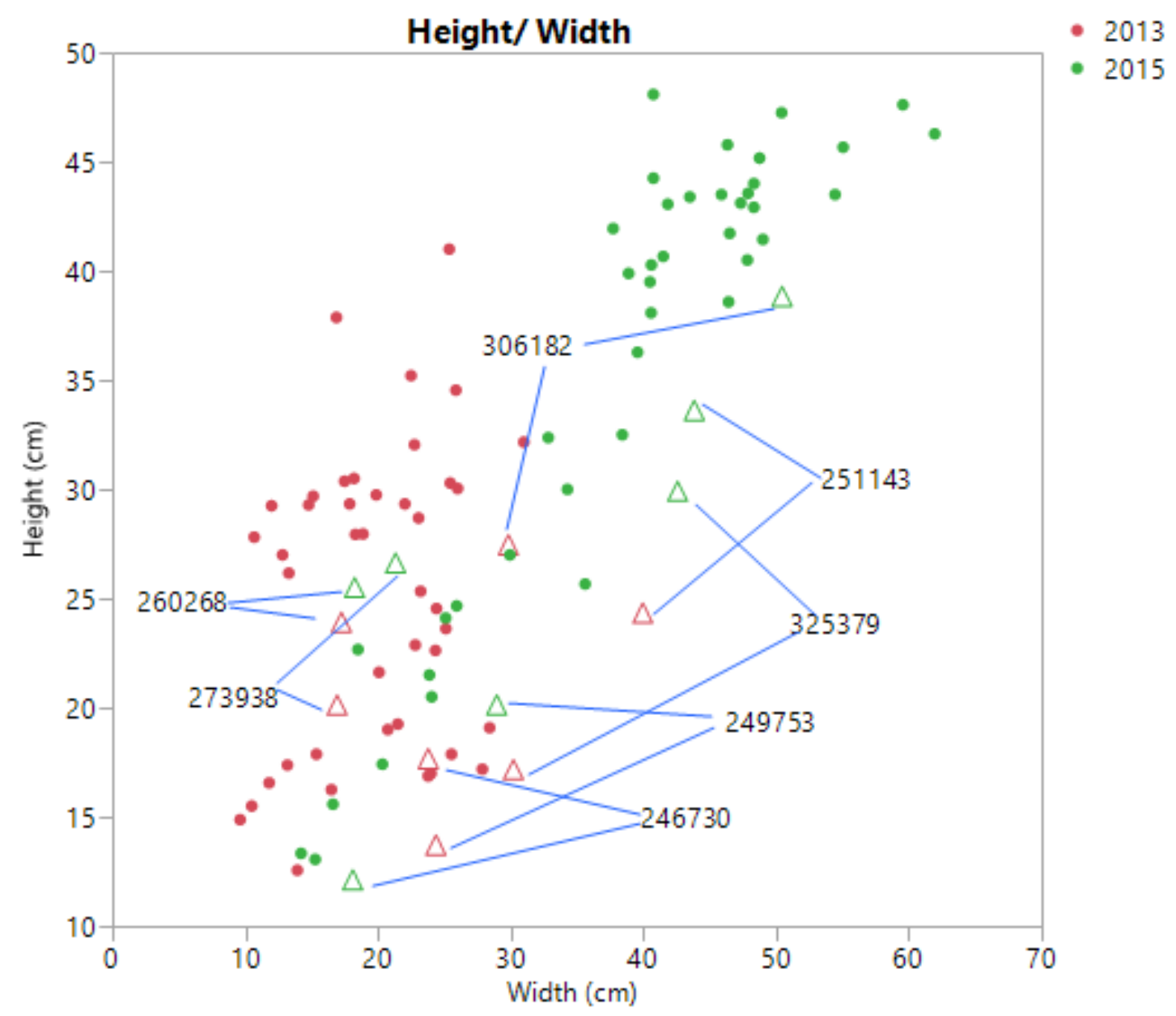

Plant vigor and uniformity scores differed significantly between populations in $2014(\mathrm{P}<0.0001, \mathrm{HSD}=2.5)$, and $2015(\mathrm{P}<0.0001, \mathrm{HSD}=2.67), 2013$ uniformity and vigor scores showed no significant differences (Figure 4). There was no significant difference between 2014 and 2015 uniformity and vigor scores. 2013 uniformity and vigor scores differed significantly from 2014 and 2015 scores. This could be because 2013 was the year of establishment and BFT is slow to establish but once established performs well. The most uniform and vigorous populations were PI306182, PI262530, PI232098 and PI262529 with a combined 2014 and 2015 score above 4.5. These four populations are all cultivar type with tannin content ranging from 11 to $29 \mathrm{~g}^{*} \mathrm{~kg}^{-1} * \mathrm{DM}$ (Roberts et. al, 1993; Grabber et. al, 2014; GRIN 
database). Cultivars are produced for agronomical use with desired characteristics selectively bred into the population which could explain why these populations had more vigor and uniformity than other populations. The least uniform and vigorous populations were PI249753, PI246730, PI273938 and PI235525 with uniformity and vigor scores at 1.0. These populations were all wild type with a higher range of tannin content from 53 to $105 \mathrm{~g}^{*} \mathrm{~kg}^{-1} * \mathrm{DM}$ (Roberts et. al, 1993; Grabber et. al, 2014; GRIN database). This could be explained by the tradeoff of plant growth and producing secondary metabolites causing uniformity and vigor to be lower (Zdant, 2007). Uniformity and vigor scores were positively correlated with plant survival, both in 2014 and 2015. Population PI421026 had a high plant survival and low uniformity and vigor, it was added in 2014 because of low germination in 2013 and was only evaluated over one winter.

Figure 4: Uniformity and vigor score histogram for 2014 and 2015.

Accessions were visually scored from 1 to 5 . A score of 1 was assigned to populations with weak and variable looking plants and a score of 5 was assigned to populations with vigorous and similar looking plants.

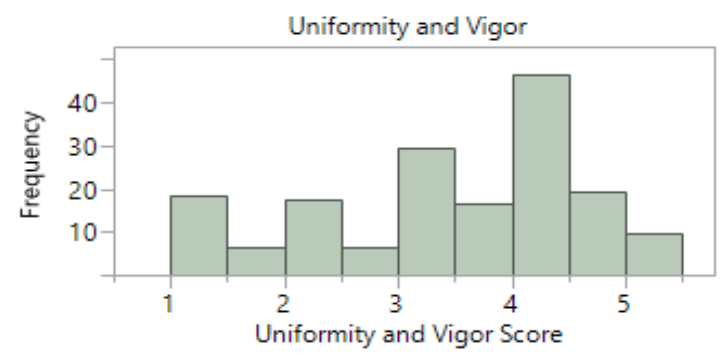

Table 1: Populations with uniformity and vigor scores averaged at 4 or above.

\begin{tabular}{|c|c|}
\hline Accession & $\begin{array}{c}\text { Uniformity and } \\
\text { Vigor Score }^{1,2}\end{array}$ \\
\hline 193725 & 4 \\
\hline
\end{tabular}




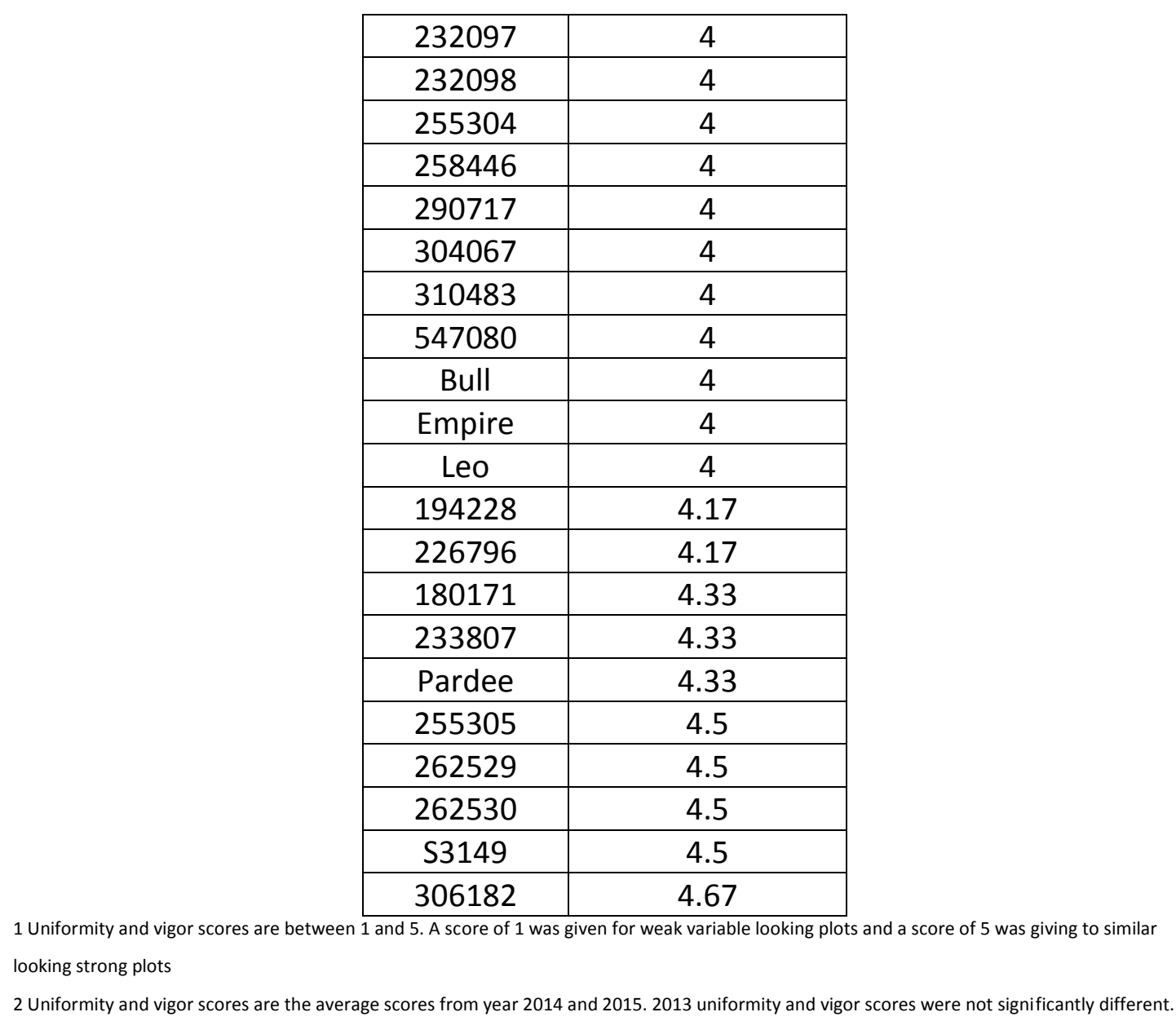

Data were collected on potato leafhopper damage in 2013 and 2015; in 2014 leafhopper populations did not reach damaging levels. Leafhopper damage can limit biomass and stunt stands of BFT which could explain why there was no significant difference in growth habit in 2014 when there was no leafhopper damage (Seaney and Hensen, 1970). Populations differed significantly in visual leafhopper damage in both $2013(\mathrm{P}<0.0001, \mathrm{HSD}=4.67)$ and $2015(\mathrm{P}<0.0001, \mathrm{HSD}=6.5)($ Figure 7$)$.

Leafhopper data for 2013 and 2015 were significantly different from each other $(\mathrm{P}<$ 0.001). Leafhopper damage in 2013 ranged from 9 to 3.33 while 2015 had a range of leafhopper damage from 9 to 1. Population PI246730 received an average leafhopper 
damage score of 9 for both 2013 and 2015. PI325379 also did well in both years. PI237278 was largely damaged with leafhopper burn both years. Leafhopper damage did not seem to be related to condensed tannin content. Leafhopper is slower to develop on BFT than on the currently used forage, alfalfa (Undersander, 1993). Both years there were populations that showed no leafhopper damage with a few populations that consistently showed little or no leafhopper damage showing ability of having a leafhopper resistant variety.

Figure 5: Leafhopper damage scores for 2013 and 2015. A score of 1 was given to populations that showed damage on more than $50 \%$ of the plants. A Score of 9 was given to populations that showed no leaf hopper damage. 

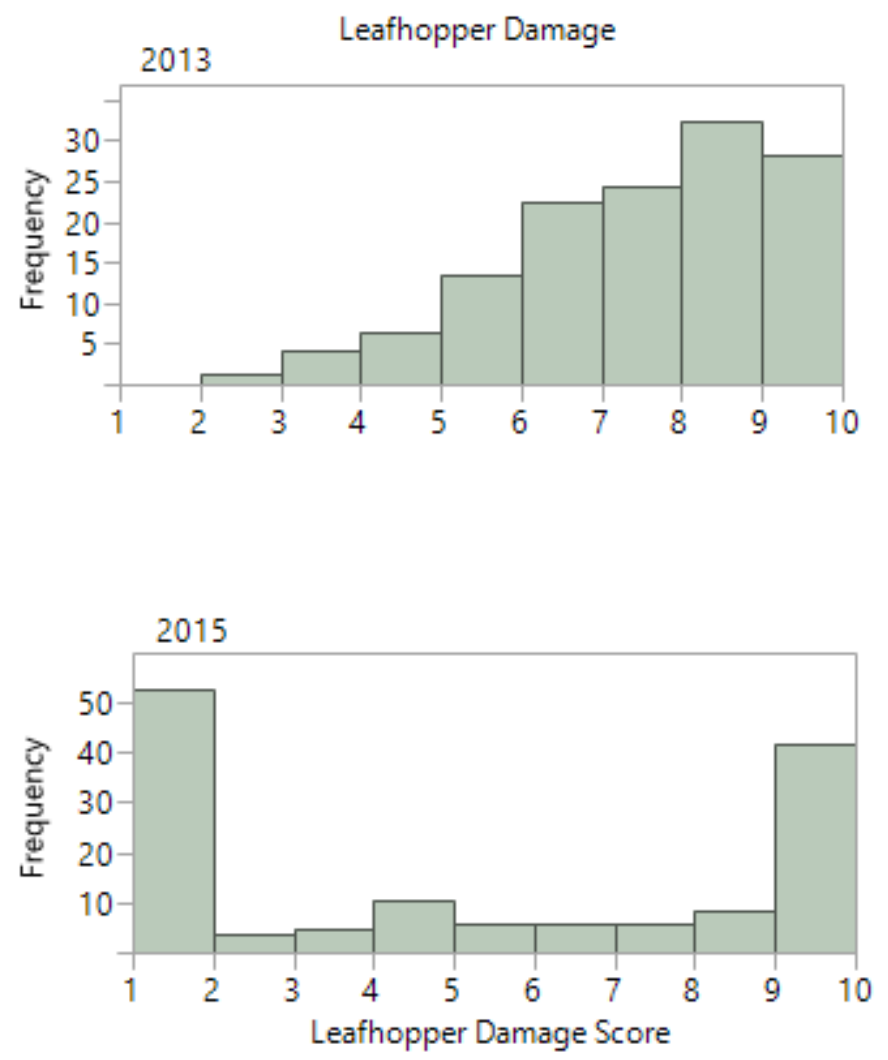

Anthelmintic efficacy was measured in vitro using an aqueous extract of lyophilized BFT leaf tissue (Barone,unpublished) and was based on percent inhibition of hatching in $H$. contortus eggs, and mortality of first instar larvae. Acessions were divided into two groups using anthelmintic efficacy data, greater than $89 \%$ inhibition and $89 \%$ and lower inhibition at $3 \mathrm{mg} / \mathrm{ml}$. There were populations with undetermined efficacy due to lack of tissue samples from poor germination and survival in the field. The eight populations that had no efficacy data included, PI421026, PI255302, PI262530, PI655626, PI249753, PI260292, PI273938, and PI273937. Egg hatch inhibition and mortality of hatched eggs included 34 populations in the low group and 15 populations in the high group, 8 populations were undetermined. All the commercial cultivars, with the exception of 'Bruce', were highly effective at 
suppressing egg hatch and killing first instar $H$. contortus larvae. Agronomic characteristics were independent of in vitro anthelmintic efficacy and tannin content, based on regression data. The identity of the anthelmintic tannin is unknown and tannin concentration changes based on environment and plant maturity (Grabber et al., 2014). If tannin content and anthelmintic efficacy are independent, it would be possible to have an agronomically well performing accession that is low in total condensed tannins but efficacious, like 'Empire'.

The 51 accessions and six commercial cultivars were grouped into 6 clusters using winter survival $\left(R^{2}=0.90\right)$, leafhopper damage $\left(R^{2}=0.74\right)$, uniformity and vigor scores $\left(R^{2}=0.54\right)$, and growth habit $\left(R^{2}=0.82\right)($ Figure 8$)$. Clusters based on agronomic traits showed no pattern in regards to tannin content, in vitro anthelmintic efficacy or origin. Cluster means are presented in table 2. Populations in cluster one showed excellent survival, good uniformity and vigor, and tolerance to leafhopper damage. Cluster two was similar except for less tolerance to leaf hopper damage. PI193725, PI162456, PI180171, PI228286, PI325379 and the commercial cultivars were clustered in group one showing strong agronomic performance with high anthelmintic efficacy (with the exception of 'Bruce'). The other five highly efficacious accessions were scattered among clusters with PI194228 and PI237278 in cluster 2, PI304523 in cluster 3, and PI227849 and PI246730 in cluster 4.

Table 2: Mean values of each cluster. Clusters include data collected in 2013, 2014 and 2015.

\begin{tabular}{|l|l|l|l|l|l|}
\hline Cluster & $\mathrm{N}$ & $\begin{array}{l}\text { Plant } \\
\text { Survival }^{1}\end{array}$ & $\begin{array}{l}\text { Hopper } \\
\text { Damage }\end{array}$ & $\begin{array}{l}\text { Uniformity } \\
\text { and Vigor }^{3}\end{array}$ & Habit $^{4}$ \\
\hline 1 & 18 & $18.41 \mathrm{a}^{5}$ & $7.81 \mathrm{a}$ & $3.61 \mathrm{ab}$ & $1.08 \mathrm{~cd}$ \\
\hline 2 & 20 & $18.78 \mathrm{a}$ & $4.34 \mathrm{c}$ & $3.90 \mathrm{a}$ & $1.13 \mathrm{c}$ \\
\hline
\end{tabular}




\begin{tabular}{|l|l|l|l|l|l|}
\hline 3 & 9 & $14.63 \mathrm{~b}$ & $5.23 \mathrm{c}$ & $3.13 \mathrm{~b}$ & $0.96 \mathrm{~cd}$ \\
\hline 4 & 7 & $8.79 \mathrm{c}$ & $7.05 \mathrm{ab}$ & $2.39 \mathrm{c}$ & $0.88 \mathrm{~d}$ \\
\hline 5 & 2 & $1.33 \mathrm{~d}$ & $6.33 \mathrm{abc}$ & $3.17 \mathrm{abc}$ & $1.63 \mathrm{~b}$ \\
\hline 6 & 1 & $0.17 \mathrm{~d}$ & $4.33 \mathrm{bc}$ & $3.83 \mathrm{abc}$ & $3.56 \mathrm{a}$ \\
\hline & 1: Plant survival out of twenty plants \\
& 2: Visible hopper damage; 1 = 50\% or more of plants showed damage, 9 = 0\% of plants showed damage \\
& 3: Uniformity and vigor score; 1 = variable and weak looking plants. 5= strong and similar looking plants. \\
& 4: Average height divided by average width for each population for 2013, 2014 and 2015. \\
5: Means not connected by the same letter are statistically different
\end{tabular}

Figure 6: Dendrogram representing the cluster analysis of all 51 accessions and six commercial cultivars based on winter survival, leafhopper damage, growth habit, vigor and uniformity data collected in 2013, 2014 and 2015. 


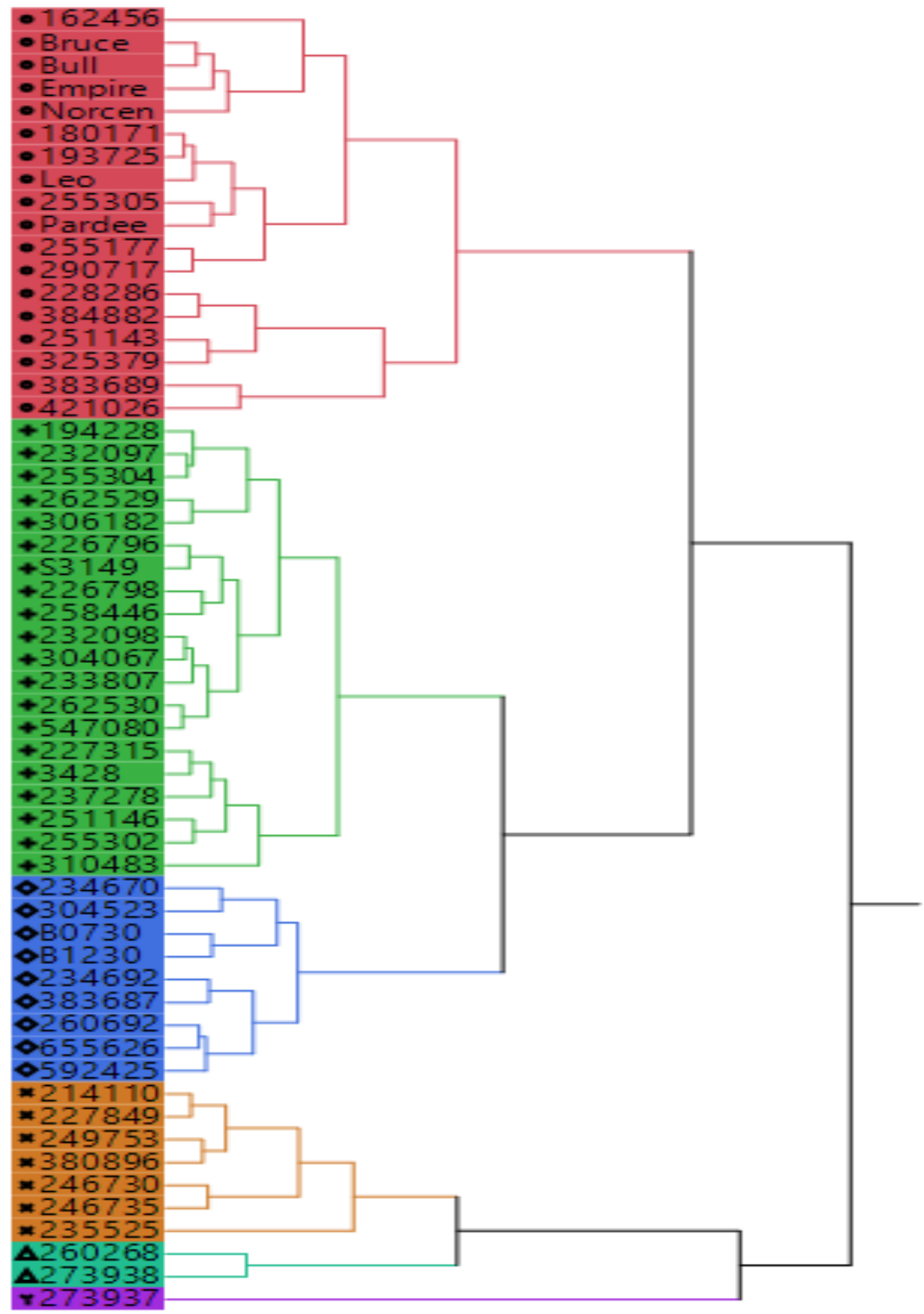

\section{Conclusion}

The 51 different PI accessions and six commercial cultivars of birdsfoot trefoil were observed for suitability for growth in the northeastern U.S. for three years. The PI accessions and commercial cultivars differed in winter hardiness, growth habit, potato leafhopper damage and uniformity and vigor. Cluster analysis revealed that accessions in cluster $1(\mathrm{~N}=18)$ had high plant survival, semi erect habit, and moderately good uniformity and vigor scores as well as low potato leafhopper 
damage. 'Pardee', 'Norcen', 'Bull', 'Empire' and 'Leo' performed well agronomically and had high anthelmintic efficacy. PI193725, PI180171, PI162456, PI228286, PI325379 were also included cluster 1 and had high in vitro anthelmintic efficacy. Four of these five accessions are 'uncertain' types and PI228286 is wild. These accessions are from varying origins including Uruguay, Czech Republic, Sweden, Iran and Ukraine. These accessions and cultivars should be further evaluated as potential parasite controls and forages in the Northeast.

\section{References:}

Elden, T. and McCaslin, M. 1997. Potato Leafhopper (Hamoptera:Ciedellidae) Resistance in Perennial Glandular-Haired Alfalfa Clones. J. Econ. Entomol. $90(3), 842-847$.

Emery, K. Beuselinck, P. English, J. 1999. Evaluation of the population dynamics of the forage legume Lotus corniculatus using matrix population models. New Phytol. 144, $549-560$.

Escaray, F. Menendez, A. Garriz, A. Pieckenstain, F. Estrella, M. Castagno, L. Carrasco, P. Sanjuan, J. Ruiz, O. 2012. Ecological and agronomic importance of the plant genus Lotus. Its application in grassland sustainability and the amelioration of constrained and contaminated soils. Plant Sci. 182, 121 - 133.

Fleming, S. Craig, T. Kaplan, R., Miller, J. Navarre, C. Rings, M. 2006. Anthelmintic Resistance of Gastrointestinal Parasites in Small Ruminants. J Vet Intern Med. 20, 435-444.

Grabber, J. Riday, H. Cassida, K. Griggs, T. Min, D. MacAdam, J. 2014. Yield, Morphological Characteristics, and Chemical Composition of European- and 
Mediterranean - Derived Birdsfoot Trefoil Cultivars Grown in the Colder Continental United States. Crop Sci. 54, 1893 - 1901.

Grant, W. 2004. List of Lotus corniculatus (Birdsfoot trefoil). McGill University, Quebec, Canada

MacAdam, J. and Griggs, T. 2006. Performance of birdsfoot trefoil, white clover, and other legume-grass mixtures under irrigation in the Intermountain West U.S.A. Proc. N.Z. Grassl. Assoc. 64, 355-359.

Min, B. and Hart, S. 2003. Tannins for the suppression of internal parasites. J Anim Sci. 81, E102 - E109.

Molan, A. Waghorn, G. McNabb, C. 1999. Condensed tannins and gastro-intestinal parasites. Proc. NZ. Grass. Assoc. 61:57-61.

National Oceanic and Atmospheric Administration (NOAA). 2016. National Center for Environmental Information, U.S. Department of Commerce. 1 Nov 2016.

Roberts, C. Beuselinck, P. Ellersieck, M. Davis, D. McGraw, R. 1993. Quantification of Tannins in Birdsfoot Trefoil Germplasm. Crop Sci. 33, 675 - 679.

Seaney, R. and Henson, P. 1970. Birdsfoot trefoil. Adv Agron. 22, 119-157.

Soil Survey Staff. 2015. Web soil survey. Natural Resources Conservation Service, U.S. Dept. Agr. 15 March 2016.

Steiner, J. Beuselinck, P. Greene, S. Kamm, J. Kirkbride, J. Roberts, C. 2001. A Description and Interpretation of the NPGS Birdsfoot Trefoil Core Subset Collection. Crop Sci. 41, 1969 - 1980.

US Climate Data Staff. 2016. U.S. Climate Data.Your Weather Service. 15 March 2016. 
USDA, 2014. Germplasm Resources Information Network (GRIN).

Undersander, D. Greub, L. Leep, R. Beuselinck, P. Wedberg, J. Smith, D. Kelling, K.

Doll, J. Cosgrove, D. Grau, C. Peterson, S. Wipfli, M. English, J. 1993.

Birdsfoot Trefoil for Grazing and Harvested Forage.

Waghorn, G. 2008. Beneficial and detrimental effects of dietary condensed tannins for sustainable sheep and goat production - Progress and challenges. Anim Feed Sci Tech. 147, $116-139$.

Zdant, V. 2007. Plant Defense Growth and Habit: a comparative assessment of constitutive and induced resistance. Ecology. 88, 1984 - 1993. 
MANUSCRIPT II

AGRONOMIC EVALUATION OF POTENTIALLY ANTHELMINTIC

BIRDSFOOT TREFOIL UNDER ROTATIONAL GRAZING IN THE NORTHEAST

\section{UNITED STATES}

BY

Sarah Ferguson ${ }^{1}$, Rebecca Brown ${ }^{2}$, Katherine Petersson $^{3}$, and Carly Barone ${ }^{4}$ Will be submitted to Crop Evolution and Genetics

${ }^{1}$ Master of Science Candidate, Department of Plant Sciences and Entomology, University of Rhode Island, Kingston, RI. Email: Sarahmarferguson@gmail.com

${ }^{2}$ Associate Professor of Plant Sciences, Department of Plant Sciences and Entomology, University of Rhode Island, Kingston, R.I. Email: brownreb@uri.edu

${ }^{3}$ Associate Professor of Animal Sciences, Department of Fisheries, Animal and Veterinary Sciences, University of Rhode Island, Kingston, R.I. Email:

Kpetersson@uri.edu

${ }^{4}$ Docteral of Science Candidate, Department of Fisheries, Animal and Veterinary Sciences, University of Rhode Island, Kingston, R.I. Email:

Carly_Barone@myuri.edu 


\title{
CHAPTER 4
}

\section{AGRONOMIC EVALUATION OF POTENTIALLY ANTHELMENTIC BIRDSFOOT TREFOIL UNDER ROTATIONAL GRAZING IN THE NORTHEAST UNITED STATES}

\begin{abstract}
:
Birdsfoot trefoil (Lotus corniculatus L.) is an adaptable forage legume with potential to control parasitic gastrointestinal nematodes in small ruminants. The objective of this research was to test the grazing tolerance, regrowth and uniformity and vigor of 19 PI accessions and 6 commercially available cultivars of birdsfoot trefoil under rotational grazing by sheep in the northeastern U.S. Nine replications were grazed twice in the summer of 2015 with 28 days rest in between grazing events. Regrowth and uniformity and vigor differed significantly between populations for both grazing events $(\mathrm{P}<0.05)$. Grazing tolerance varied widely with a low of $56.92 \%$ for PI232098 and a high of $95.06 \%$ for 'Empire'. Grazing tolerance and uniformity and vigor were positively correlated with anthelmintic efficacy. Regrowth was independent of efficacy. This research identifies commercial cultivars and PI accessions with potential for use as medicinal pasture against $H$. contortus in the northeastern U.S.
\end{abstract}

Key Words: Lotus corniculatus L., legume forage, grazing variety trial, tanniferous forage 


\section{Introduction:}

Gastrointestinal parasites cause economic losses in sheep production worldwide, with the most pathogenic parasite being Haemonchus controtus (Min and Hart, 2003). Currently commercial anthelmintic treatments are used to control $H$. contortus (Hale, 2006). There are three different classes of drugs available on the U.S. market including benzimbadazole, nicotinic agonist and macrocylic lactone (Hale, 2006). Organic producers cannot market product as organic if they treat animals with synthetic anthelmintics, but have no other economically viable option (Haring et al., 2008). Routine use of synthetic anthelmintics leads to development of drug resistance in the $H$. contortus population; parasite resistance has been documented to all three drug types currently available (Fleming et al., 2006). Studies have shown that tanniferous forages suppress H. contortus in sheep (Min and Hart, 2003). The mechanism of the direct anthelmintic effect is still not clearly understood (Waghorn, 2008). Moderate amounts of tannins suppress worm burden symptoms indirectly by allowing an increase in available protein and amino acids, building an increased tolerance to the nematode (Haring, 2008). The condensed tannins can bind to protein and prevent degradation in the rumen allowing more amino acids to be absorbed in the small intestine (Waghorn, 2008). As the structural profile of the anthelmintic tannins is unknown, previous studies have correlated efficacy to total condensed tannin levels (Min and Hart, 2003; Grabber et al., 2014). However, forages high in condensed tannins (over $55 \mathrm{~g} \mathrm{CT} / \mathrm{kg}$ of dry matter) are less palatable for grazing ruminants and can have negative effects on sheep such as limiting growth and wool production (Min and Hart, 2003). In the southern US Lespedza cuneate L. is used as a medicinal forage 
to control H. contortus in small ruminants (Mechineni et al., 2014). Lespedza cuneata is not an option for the northeastern US because it is a perennial and does not overwinter where temperatures are below $-18^{\circ} \mathrm{C}$.

Birdsfoot trefoil (Lotus corniculatus L.) is a tanniferous forage legume that is adapted to the Northeast and has been shown to decrease fecal egg counts in small ruminants (Waghorn, 2008). Additional benefits of birdsfoot trefoil (BFT) incorporated in diets include increased protein and amino acid intake without bloating, increased wool production and increased weight gain (Fleming et al., 2006). Birdsfoot trefoil also has environmental benefits including reducing methane and ammonia emissions from ruminants and converting atmospheric nitrogen to forms useable by plants and animals (MacAdam et al., 2006).

Breeding programs in the United States and Canada have been developing high yielding new varieties adapted to the Midwest, but few varieties adapted to New England have been produced since the 1970s, and old varieties are generally unavailable. On well drained fertile land, BFT does not yield as well as alfalfa (Grabber et al., 2014). The challenges associated with growing BFT are seed harvesting, stand establishment, and susceptability to root and crown rot (Seaney and Hensen, 1970). Birdsfoot trefoil plants only live for two to three years but reseed themselves, creating a population matrix with different developmental stages within a stand. Once pasture is established BFT can produce yields for many years with minimal input due to self seeding (Emery et al., 1999).

Birdsfoot trefoil shows two distinct growth habits: European type which is more erect and adapted to haying and Empire type which is more prostrate and adapted to 
grazing (Undersander, 1993). Although the European type plants are more vigorous and regrow quickly after being harvested the Empire type plants produce a better quality of forage due to thin stems and indeterminate growth (Undersander, 1993). New cultivars of BFT are routinely tested in mowed forage trials, but are rarely tested under grazing conditions (Hansen et al., 2012; MacAdam and Griggs, 2013).

Birdsfoot trefoil, once established, is persistent under grazing when grown in mixtures with grass (MacAdam et al., 2006). Heavy grazing is not recommended as BFT keeps energy reserves in the top growth as opposed to the roots (Undersander et al., 1993). A minimum height of $7 \mathrm{~cm}$ will allow for regrowth to occur without damaging the BFT. Overgrazing of BFT will prevent regrowth and promote winter injury (Undersander et al., 1993). Birdsfoot trefoil should not be grazed within 5 to 6 weeks of the first frost to allow for regrowth and to prevent winter injury (Schaller et al., 1997). Undersander et al. (1993) recommends that BFT not be grazed after midAugust in the North Central US region to allow for recovery to increase stand persistence, in the Northeast BFT can be grazed into September.

Grazing trials are needed in agronomic performance studies of forages to identify accessions that will be able to tolerate trampling and defoliation and to determine the amount of rest time needed in between grazing events (Sollenberger, 2015). Pecetti et al. (2009) tested a semi erect germplasm and an erect variety of BFT for grazing tolerance in a four-year trial in Italy. The semi erect germplasm was specifically selected for grazing tolerance. The erect variety persisted as well as or better than the selected semi erect germplasm. 
Many birdsfoot trefoil grazing trials in the literature focus on the animal outcome, meaning the cultivars used may not even be identified. Studies have shown a positive outcome of more wool production, higher weight gains, and lower fecal egg counts in animals grazing on BFT. Data have been collected on specific varieties for specific regions but variety trials have not included testing under rotational grazing (Grabber et al., 2014; Steiner et al., 2001; McGraw et al., 1989; Haring et al., 2007). Most studies of BFT as a medicinal forage have not attempted to relate agronomic performance and efficacy as a medicine. The objective of this study was to evaluate 19 PI accessions and six commercial cultivars of birdsfoot trefoil for grazing tolerance, uniformity and vigor and regrowth in the northeastern U.S. using a rotational grazing trial, and to relate these characteristics to anthelmintic efficacy against $H$. contortus.

\section{Materials and Methods:}

\section{Site Description:}

The experimental plot was established in September 2012 at Peckham Farm at The University of Rhode Island in Kingston, RI. The soil in this part of the farm is a mixture of Bridgehampton silt loam and Enfield silt loam with a 0-3\% slope (Web Soil Survey Staff, 2015). The trial took place in 2015 with the rainfall totaling 312.2 $\mathrm{mm}$ for the growing season and temperature ranging from 5.8 to $30.5^{\circ} \mathrm{C}$ (NOAA, 2016). The field was in minimally managed grass pasture for many years prior to being tilled and seeded to orchard grass (Dactylis glomerata L.) in September 2012. Plant Selection

This project included 6 commercial cultivars commonly grown in the US and Canada and 19 PI accessions from the National Germplasm System (Pullman, WA) and 
university breeding programs (Minneapolis, MN; Ithaca, NY) (Table 1). The PI accessions were selected based on vigor, growth habit, winter survival and potato leafhopper (Empoasca fabae) tolerance from a set of $51 \mathrm{PI}$ accessions with low to moderate levels of condensed tannins using data from the 2013 growing season at the University of Rhode Island (Ferguson, Unpublished). Plant introductory accessions that excelled for one or more evaluated traits were chosen from each growth habit group to be further evaluated in the grazing trial.

Table 1: 19 PI accessions and 6 commercial cultivars that were evaluated in the grazing trial. The $20 \mathrm{PI}$ accessions were chosen from preliminary evaluation in 2013 (Ferguson, Unpublished).

\begin{tabular}{lllc}
\hline Accessions & $\begin{array}{l}\text { Strong } \\
\text { agronomic } \\
\text { Characteristic }\end{array}$ & Origin & $\begin{array}{l}\text { Tannin } \\
\text { Content } \\
\left(\mathbf{g}^{*} \mathbf{k g}^{\mathbf{1} * \mathbf{D M})} \mathbf{~}^{\mathbf{1}}\right.\end{array}$ \\
\hline B0730 & $\begin{array}{l}\text { Tolerance to } \\
\text { potato leaf } \\
\text { hopper }\end{array}$ & United States & \\
\hline Bull & $\begin{array}{l}\text { Commercial } \\
\text { Cultivar }\end{array}$ & Canada & \\
\hline Bruce & $\begin{array}{l}\text { Commercial } \\
\text { Cultivar }\end{array}$ & United States & \\
\hline Norcen & $\begin{array}{l}\text { Commercial } \\
\text { Cultivar }\end{array}$ & United States & 19.3 \\
\hline Pardee & $\begin{array}{l}\text { Commercial } \\
\text { Cultivar }\end{array}$ & United States & 20 \\
\hline Leo & $\begin{array}{l}\text { Commercial } \\
\text { Cultivar }\end{array}$ & United States & 11 \\
\hline Empire & $\begin{array}{l}\text { Commercial } \\
\text { Cultivar }\end{array}$ & United States & 3 \\
\hline $\mathbf{1 9 3 7 2 5}$ & Vigor & Sweden & 25 \\
\hline $\mathbf{2 1 4 1 1 0}$ & $\begin{array}{l}\text { Tolerance to } \\
\text { potato leaf } \\
\text { hopper } \\
\text { Vigor }\end{array}$ & Spain & 66 \\
$\mathbf{2 2 6 7 9 6}$ & Canada & 26 \\
\hline
\end{tabular}




\begin{tabular}{|c|c|c|c|}
\hline 232097 & Vigor & Germany & 25 \\
\hline 232098 & Vigor & Germany & 26 \\
\hline 246730 & $\begin{array}{l}\text { Habit - semi } \\
\text { erect }\end{array}$ & United States & 68 \\
\hline 246735 & $\begin{array}{l}\text { Tolerance to } \\
\text { potato leaf } \\
\text { hopper }\end{array}$ & United States & 69 \\
\hline 251143 & $\begin{array}{l}\text { Habit - } \\
\text { prostrate }\end{array}$ & Macedonia & 17 \\
\hline 255177 & Vigor & Poland & 22 \\
\hline 304067 & Vigor & Uruguay & 31 \\
\hline 304523 & $\begin{array}{l}\text { Tolerance to } \\
\text { potato leaf } \\
\text { hopper }\end{array}$ & Turkey & 4 \\
\hline 306182 & Vigor & United States & 11 \\
\hline 380896 & $\begin{array}{l}\text { Habit - semi } \\
\text { erect }\end{array}$ & Iran & 4 \\
\hline 383689 & $\begin{array}{l}\text { Tolerance to } \\
\text { potato leaf } \\
\text { hopper }\end{array}$ & Turkey & 7 \\
\hline 655626 & $\begin{array}{l}\text { Tolerance to } \\
\text { potato leaf } \\
\text { hopper }\end{array}$ & United States & \\
\hline $228286^{3}$ & $\begin{array}{l}\text { Habit - semi } \\
\text { erect }\end{array}$ & Iran & 4 \\
\hline $3^{325379^{3}}$ & $\begin{array}{l}\text { Habit - } \\
\text { prostrate }\end{array}$ & $\begin{array}{l}\text { Former Soviet } \\
\text { Union }\end{array}$ & 6 \\
\hline $384882^{3}$ & $\begin{array}{l}\text { Habit - semi } \\
\text { erect }\end{array}$ & Iran & 4 \\
\hline
\end{tabular}

1: 'The strong agronomic characteristic' is the reason the accession was chosen from the 2013 evaluation.

2: Origin and the tannin content from GRIN database; Roberts et al., 1993; Grabber et al., 2014

3: Accession was not included in data collection because of excessive mortality over the winter of 2014-2015

Plant Production:

The BFT plants for the grazing trial were vegetatively propagated from plants in the 2013 field nursery in September 2013 (Ferguson, Unpublished). This was necessary because of the limited quantity of seed available for PI accessions, and 
generally poor germination rates. Further vegetative propagation was done in late January 2014 using the two-node stem cut method (Seaney and Hensen 1970). Cuttings were stuck into 72 - count plug trays filled with Organic Mechanics mix (The Organic Mechanics Soil Company, Chester County, PA) and placed in the greenhouse under mist. The misters were on twice a day, from 8:00am until 8:20am and again from 4:30pm to $4: 50 \mathrm{pm}$. The greenhouse was kept between $18.3^{\circ} \mathrm{C}$ and $22.2^{\circ} \mathrm{C}$. Once the cuttings were rooted they were transplanted to 38 -count plug trays and then in late November transplanted to $7.5 \mathrm{~cm}$ square pots. The cuttings were treated with organic liquid fertilizer (Neptune's Harvest, Gloucester, MA; MiracleGro® Organic Choice ${ }^{\circledR}$ All Purpose Plant Food Concentrate, Marysville, OH) weekly and watered daily. The BFT plants were treated twice for aphids by releasing parasitoids in the greenhouse and cutting back the herbage to $12.5 \mathrm{~cm}$ (February 17 and March 31,2014). The BFT plants were hardened off outside in early May before being transplanted to field plots. Additional cuttings were vegetatively propagated in April 2014 from the field nursery to replace any accessions that were lost due to aphids.

Plants of commercial cultivars were started from seed in the greenhouse using Organic Mechanics mix in trays under a mister in early March 2014. The greenhouse was kept between $18.3^{\circ} \mathrm{C}$ and $22.2^{\circ} \mathrm{C}$. Once the seedlings were rooted they were transplanted to 38 -count plug trays and then transplanted in April to $7.5 \mathrm{~cm}$ square pots. The seedlings were treated with organic liquid fertilizer weekly and watered daily. The BFT plants were hardened off outside in early May before being transplanted to field plots. 
Experimental Plot Establishment:

The BFT was transplanted into an established stand of orchard grass. Prior to transplanting the orchard grass was mowed to $9 \mathrm{~cm}$ using a rotary mower. Holes with a diameter of $7.5 \mathrm{~cm}$ and a depth of $15 \mathrm{~cm}$ were dug using an auger. Transplants were placed in the holes by hand, and holes were backfilled with Organic Mechanics mix inoculated with Rhizobium leguminosarum biovar vicege (N-Dure INTX Microbials

LLC, Kentland, IN). Each plant was watered immediately after planting. The 9 replications, each measuring $5 \mathrm{~m} \times 84 \mathrm{~m}$, were laid out with populations of the PI accessions and commercial cultivars of BFT arranged in a randomized block design $(n=25)$. Each replication was a separate grazing area that contained one plot of each of the 25 accessions and cultivars. Each plot consisted of nine plants set up in a square block, three rows of three, which measured $61 \mathrm{~cm}$ by $61 \mathrm{~cm}$. Plants that were winter killed from 2014 to 2015 were replaced with transplants from within the field that were of same maturity and age of existing plants.

Experimental Plot Maintenance

The 2015 growing season was very dry with only $312.2 \mathrm{~mm}$ of precipitation from June to August, particularly with only $75.2 \mathrm{~mm}$ of precipitation in August (NOAA, 2016). Due to the very dry growing season in 2015 the entire grazing area was watered using a water reel sprinkler (Big Sprinkler, Yukon, Oklahoma) once in early June and 3 times in August (August 10, $20 \& 28$ ). The sprinkler head was adjusted to full rotation at setting 3 and PSI of 60 and the sprinkler was wheeled out in between replications three and four and again in between replications six and seven. Each watering date there was approximately 2880 liters delivered to the entire area. 
The study area was fertilized each year in early May. In 2014 the field was fertilized with 8-1-9 organic fertilizer (Nature's Turf, Bradford, VT) at $489.5 \mathrm{~kg} / \mathrm{ha}$. In 2015 the field was fertilized with $33 \mathrm{~kg} / \mathrm{ha}$ nitrogen, $49.5 \mathrm{~kg} / \mathrm{ha}$ phosphorous, and $99 \mathrm{~kg} / \mathrm{ha}$ potassium (Vtown Ag Supply, Voluntown, CT).

Grazing Trial:

Grazing and evaluation took place from July 2015 to September 2015. Fifteen sheep and one donkey grazed each replication for a 24-hour period to a target height of 7.5 $\mathrm{cm}$. The donkey was kept with the sheep as a guard against coyotes and feral dogs. Each replication was grazed twice with 28 days rest in between (Table 2). There were nine grazing sections, each containing one replication. The sections were separated using three strings of electric fence to block off access to additional grazing sections. The sheep and donkey had access to water and a shade structure at all times. The stocking rate was determined experimentally. Thirty sheep and one donkey took roughly 12 hours to graze the orchard grass in a test strip of the same size as a replication to the optimum height of $7.5 \mathrm{~cm}$ and by 24 hours the test strip was completely overgrazed to stubble. By cutting the number of sheep in half overgrazing was prevented and the sheep and donkey only had to be moved once every 24 hours. Each replication was mowed to $30.5 \mathrm{~cm}$ one to two days before the first round of grazing with a tractor- mounted rotary mower (Table 2). The 15 sheep and 1 donkey were brought into each grazing section at 8:30 am and removed the following day at 8:30 am. Each BFT plant was measured before and after each grazing period, and then weekly for four weeks post grazing. To measure a plant a meter stick was placed in the center of the crown and the plant was pulled upwards measuring the longest branch of 
the plant from the crown to the tip in centimeters. Before each grazing period combined uniformity and vigor were visually evaluated on a scale of 1 - 10 with a score of 1 indicating variable, weak looking plants and a score of 10 indicating uniform and strong looking plants that filled in the plot with an abundance of herbage. A score of 5 was a population with greater than $50 \%$ of the plants showing good growth and solid establishment. Plant deaths during grazing or the rest time were recorded to determine grazing tolerance.

Table 2: Mowing and rotational grazing schedule for each of the nine replications.

\begin{tabular}{|c|c|c|c|}
\hline Replication & Mowing Date & Grazing Period 1 & Grazing Period 2 \\
\hline 1 & July 7 & July 9 & August 6 \\
\hline 2 & August 3 & August 4 & September 1 \\
\hline 3 & August 3 & August 5 & September 2 \\
\hline 4 & July 13 & July 14 & August 11 \\
\hline 5 & July 13 & July 15 & August 12 \\
\hline 6 & July 21 & July 22 & August 19 \\
\hline 7 & July 21 & July 23 & August 20 \\
\hline 8 & July 27 & July 28 & August 25 \\
\hline 9 & July 27 & July 29 & August 26 \\
\hline
\end{tabular}

\section{Statistical Analysis}

The grazing area was laid out in a randomized plot design with nine replications. Data were collected for grazing tolerance, regrowth rate and uniformity from July to September 2015. Using JMP ${ }^{\circledR}$ statistical discovery (Statistical Analysis System Inst., Cary, NC) data were checked for normal distribution and transformed where appropriate. Repeated measures analysis of variance test was done to test for significance. A p-value of 0.05 or below was considered significant. Tukey's HSD test was used for means comparisons.

\section{Results and Discussion:}


The first replication was removed from statistical analysis because it differed significantly from the other replications. The birdsfoot trefoil and orchard grass were grazed significantly lower in the first replication. This difference could be because sheep that forage new pastures have an increased intake that levels out as the animals spend longer on a pasture (Baumont et al., 2000).

Regrowth differed $(\mathrm{P}<0.001)$ among accessions and cultivars over the 8 weeks of measurement (Figure 1 and Figure 2). The range of regrowth for the first grazing event until the second grazing event was $6.82 \mathrm{~cm}$ for PI232098 to $14.20 \mathrm{~cm}$ for 'Empire' (HSD: $4.67 \mathrm{~cm}$ ) (Figure 1). The range of regrowth from the second grazing event until the termination of the trial (week 8) was from $6.53 \mathrm{~cm}$ for PI232098 to $14.25 \mathrm{~cm}$ growth for 'Empire' (HSD: $4.45 \mathrm{~cm}$ ) (Figure 2). The six commercial cultivars were all within the top 7 accessions for regrowth. PI accessions that performed significantly better than the other accessions for regrowth over both grazing events included PI193725, PI255177 and PI306182 (HSD: 1.61). The post grazing measurements for the second grazing event were significantly lower $(\mathrm{P}=$ 0.0038) than the post grazing measurements of the first grazing event (Figure 3). Grazing tolerance was clearly weaker in PI 246730, with the largest decreased growth mean of $4.5 \mathrm{~cm}$. This could indicate that the BFT did not have a long enough rest period in between grazing events. There were significant differences $(\mathrm{P}=0.0001)$ between post grazing measurements among accessions (Figure 3). 
Figure 1: Regrowth after grazing event 1 until week 4.

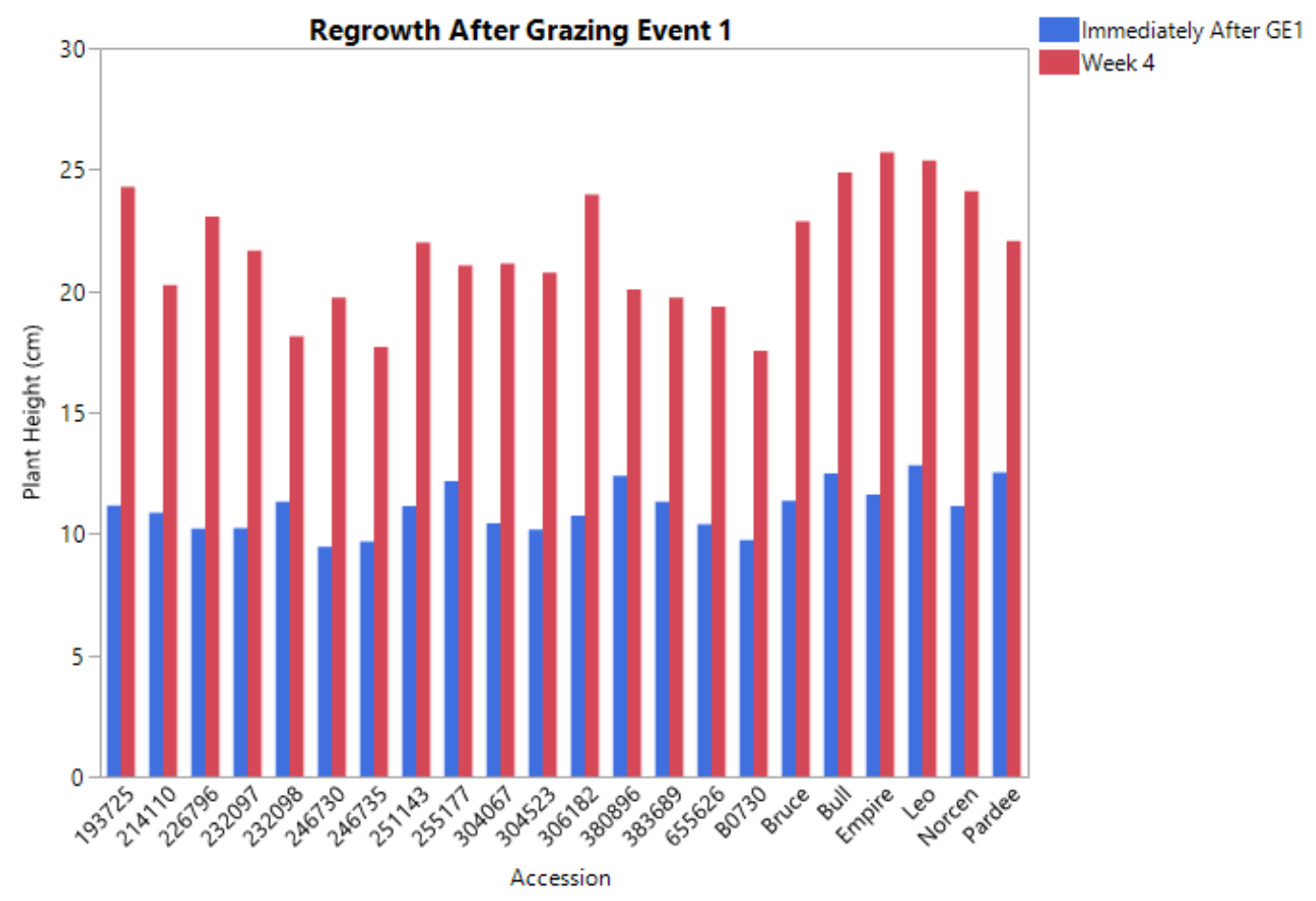

Figure 2: Regrowth after grazing event 2 until week 8.

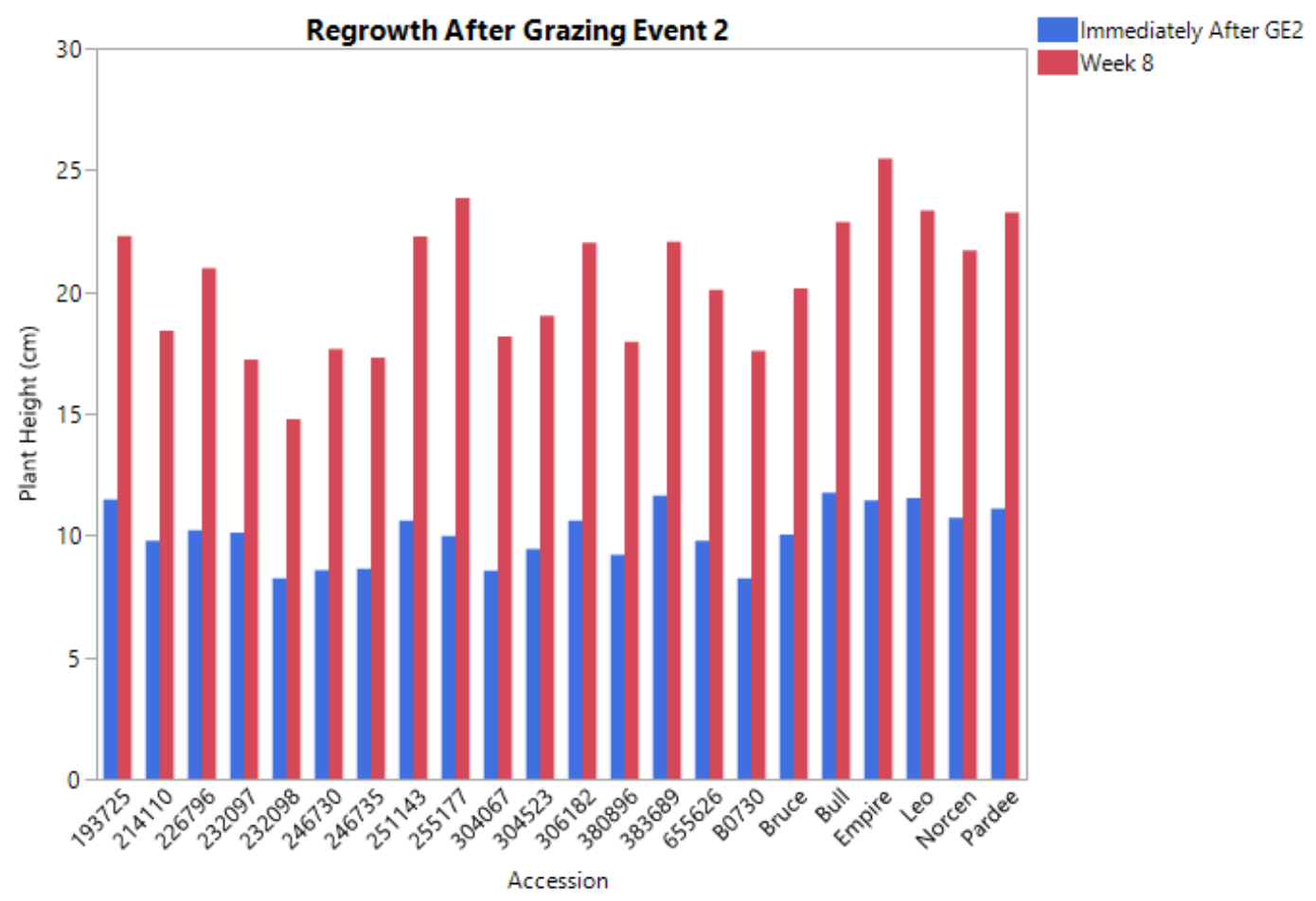


Combined vigor and uniformity was recorded for each plot immediately before each grazing event (Figure 4). There was a significant difference $(\mathrm{P}<0.0001)$ between accessions and cultivars immediately before grazing event 2 (HSD: 3.42 ) but not before grazing event $1(\mathrm{P}=0.06)$. There was a significant difference in vigor and uniformity scores $(\mathrm{P}=0.0001)$ between $\mathrm{PI}$ accessions (mean $=5.02 \pm 0.18)$ and commercial cultivars (mean $=6.32 \pm 0.26)$ (Figure 5). This was to be expected as cultivars have been bred for uniformity and vigor. The mean uniformity and vigor score for the entire trial across both grazing periods was $5.44 \pm 0.69$ with the range being 1 to 10 for all entries. There was a decline in uniformity and vigor across all populations between grazing events but it was not significant. This could indicate a slight decline in stand persistence or it could be a response to weather, temperature, moisture or light exposure. Despite the overall decline in uniformity and vigor between grazing events there were several accessions that retained uniformity and vigor including 'Empire', 'Leo', PI306182 and PI304523. 
Figure 3: Post grazing measurements $(\mathrm{cm})$. Plant heights were measured immediately after grazing events. Error bars represent the standard error from the mean.

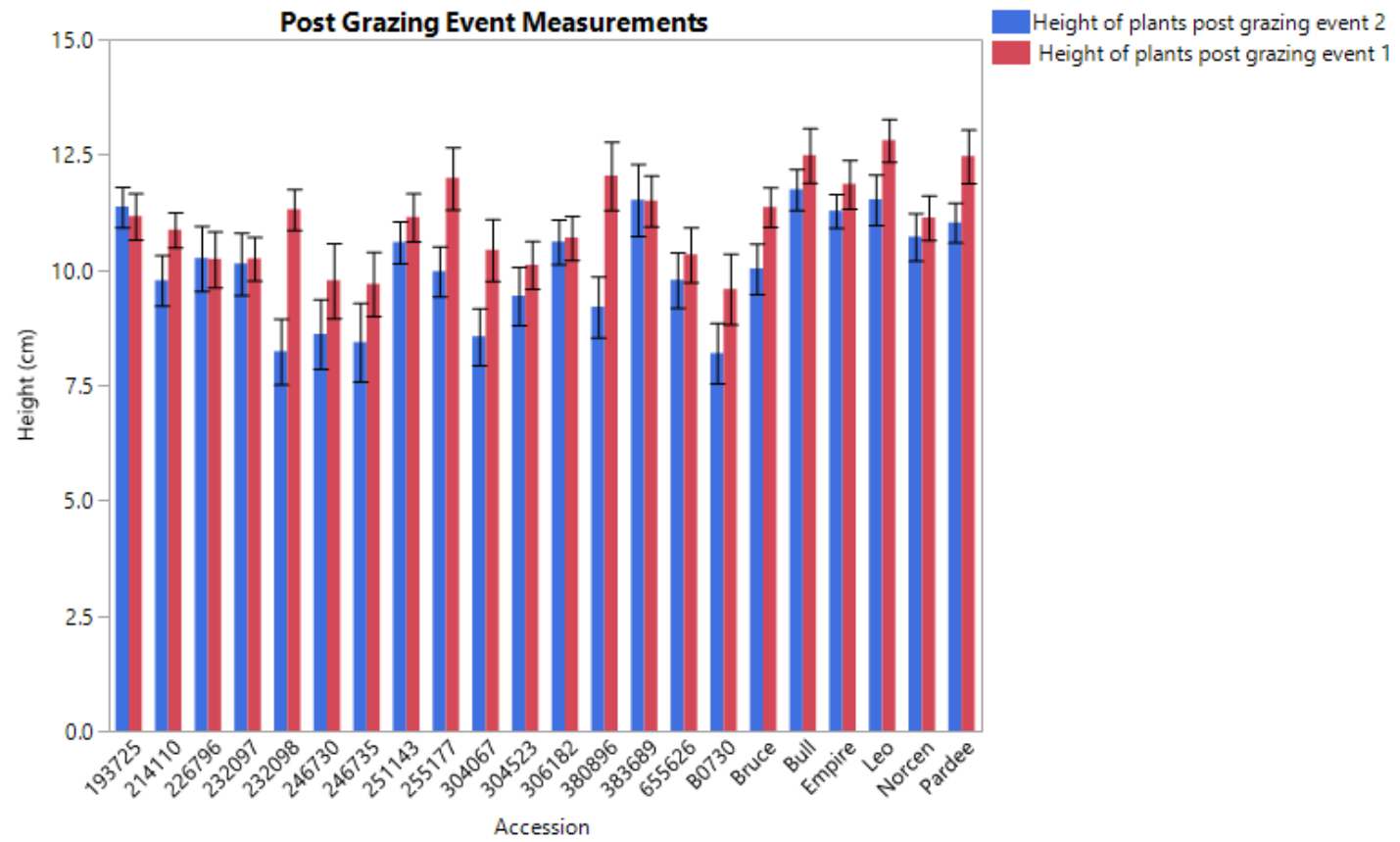


Figure 4: Combined uniformity and vigor scores immediately before each grazing event. Uniformity and vigor was visually evaluated on a scale of 1 to 10 . Decrease in score after the first grazing event could indicate a lack of grazing tolerance. Population 380896 was identified as an outlier which could indicate poor grazing tolerance.

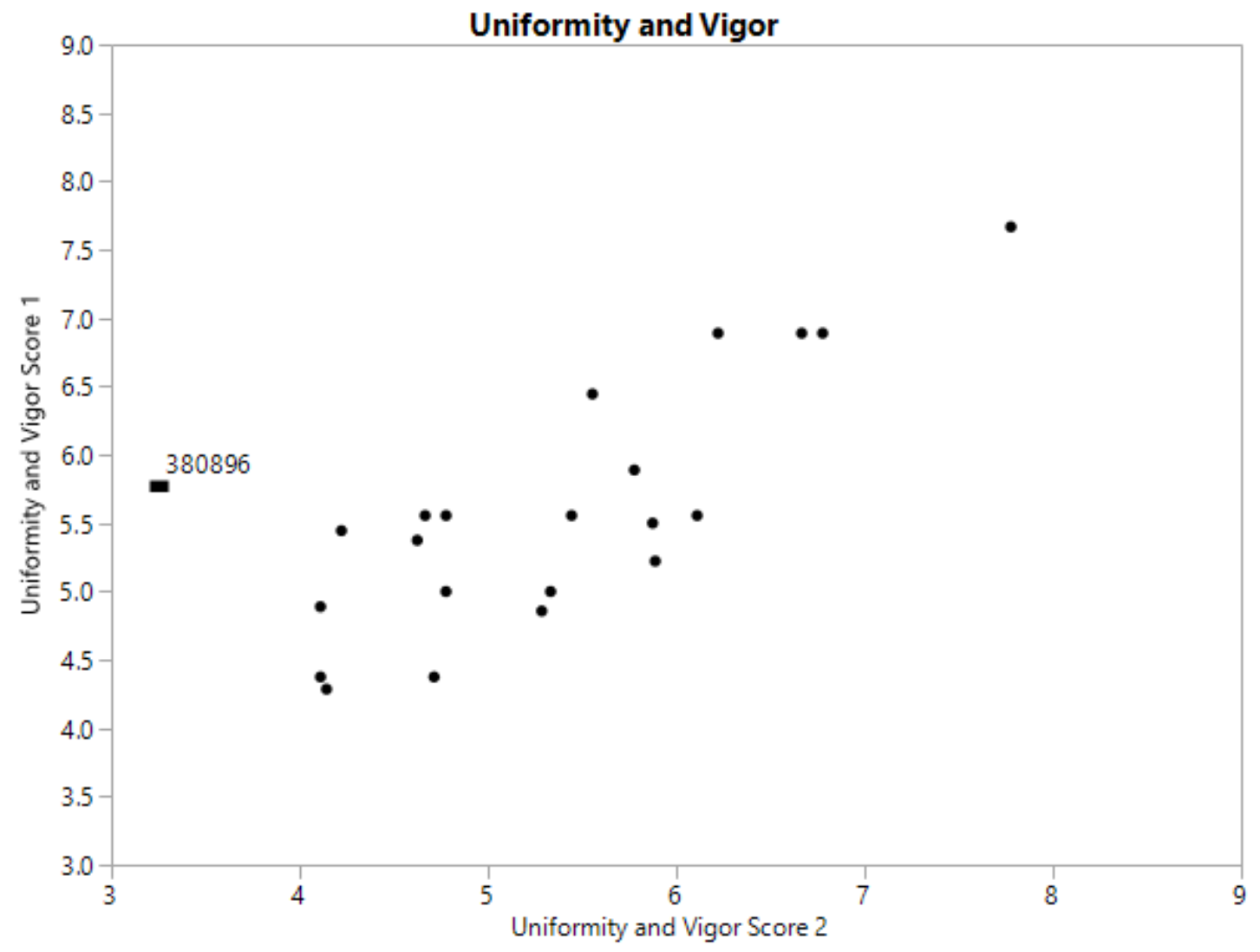


Figure 5: Average combined uniformity and vigor scores between PI accessions and commercial cultivars immediately before each grazing event.

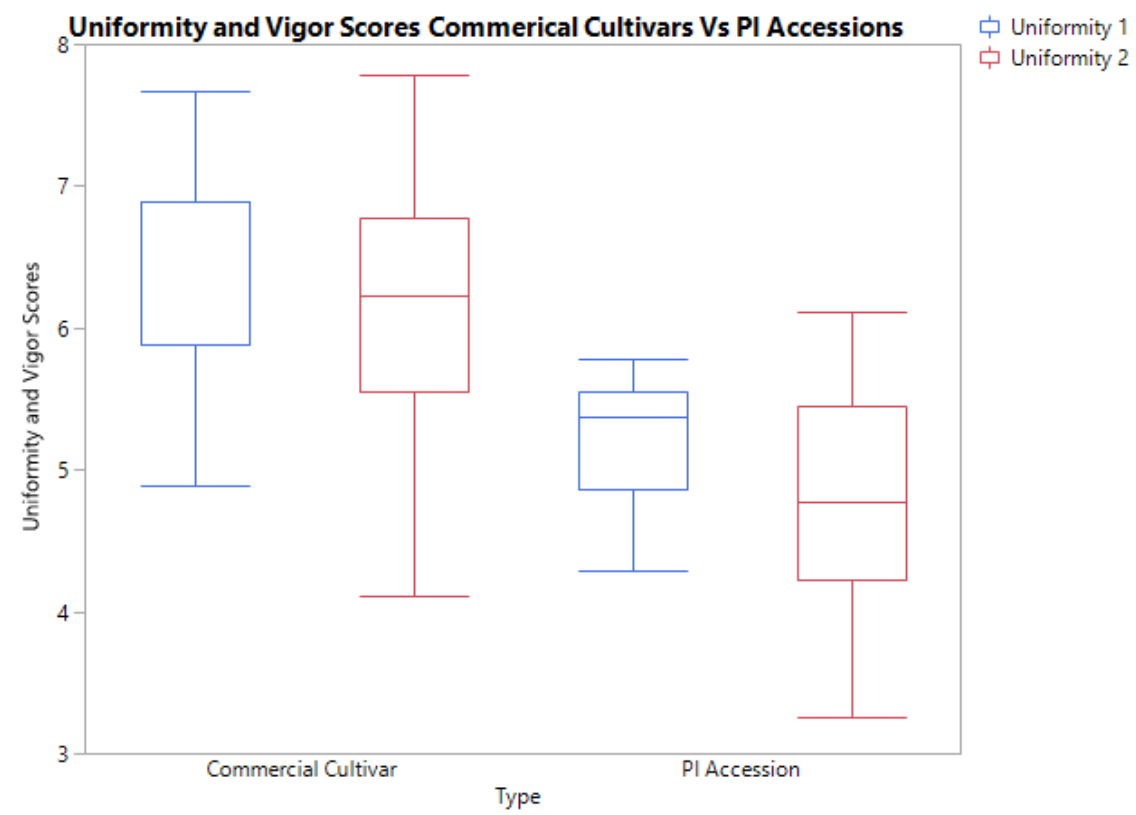

Plant survival was determined at the termination of data collection (week 8) and varied widely with a low of 57\% for PI232098 and a high of 95\% for 'Empire'. Post grazing measurements for both grazing events were positively correlated with survival rates (Post $1 ; R^{2}=0.26 \mathrm{df}=21$, Post $2 ; \mathrm{R}^{2}=0.79 \mathrm{df}=21$ ) (Figure 6). The lower an accession was grazed the lower the survival rate. 'B0730' had one of the lowest survival rates (70\%) and one of the highest rates for plants grazed $7 \mathrm{~cm}$ or below (28\%). This could indicate that some areas were overgrazed or that that sheep prefer these populations. There was a significant correlation between uniformity and vigor scores and plant survival rate (Uniformity and vigor score 1 and plants survival $\mathrm{R}^{2}=$ $0.55, \mathrm{df}=21$; Uniformity and vigor score 2 and plant survival $\mathrm{R}^{2}=0.60$, $\mathrm{df}=21$ ). Accessions that showed weak plants prior to grazing often had a decline in plant 
survival. There was evidence of weak roots allowing the sheep to pull up the plant while grazing. This could also indicate the plants had a lack of vigor and resources so were not available to regrow after grazing. There was also a significant regression $(\mathrm{P}=$ 0.0032) between plants that were replaced with transplants and plant survival.

Transplanted plants may have not had enough time to establish a strong root system before grazing.

Figure 6: Regression between plant survival rate and post grazing measurements. Plants survival rate was determined at 8 weeks. Post grazing heights were measured immediately after each grazing event.

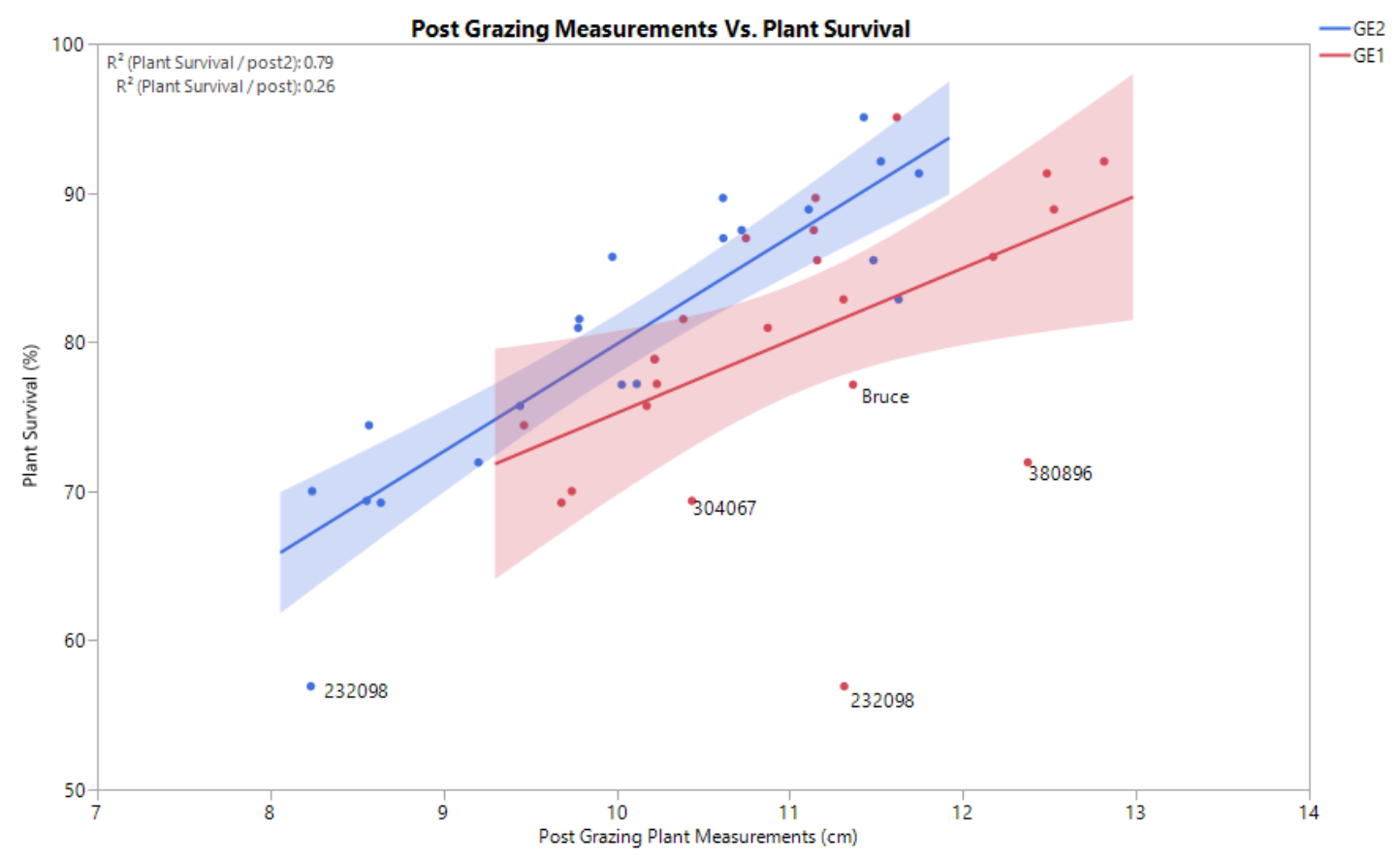

European type plants are more vigorous and regrow quickly after being harvested while the Empire type plants have thin stems and indeterminate growth, which produce a better quality of forage (Undersander et al., 1993). Height/width ratios is a measurement of growth habit. Accession height/width ratio data from field 
plantings (Ferguson, unpublished) were correlated with the regrowth rate after both grazing events. European type plants showed more regrowth than empire type plants consistent with Undersander (1993). There was a significant regression $(\mathrm{P}=0.02)$ between height/width ratio averaged over three years and the regrowth measurements after the second grazing event but there was a weak correlation $\left(\mathrm{R}^{2}=0.24, \mathrm{DF}=21\right)$. There was no significant relationship between the regrowth after the first grazing event and the height/width ratio.

Anthelmintic efficacy was measured in vitro using an aqueous extract of lyophilized BFT leaf tissue (Barone,unpublished) and was based on percent inhibition of hatching in $H$. contortus eggs, and mortality of first instar larvae. Anthelmintic efficacy was divided into two groups, greater than $89 \%$ inhibition and $89 \%$ and below inhibition at $3 \mathrm{mg} / \mathrm{ml}$. Accession 655626 had undetermined in vitro efficacy due to lack of tissue samples from poor germination and survival in the field.. Egg hatch inhibition and mortality of hatched eggs included 14 populations in the low group and 8 populations in the high group. All the commercial cultivars, with the exception of 'Bruce', were highly effective at suppressing egg hatch and killing first instar $H$. contortus larvae. Birdsfoot trefoil survival rate did differ significantly between the efficacy groups $(\mathrm{P}=0.02)$, with the accessions with the highest efficacy also having the best survival (Figure 7). Birdsfoot trefoil uniformity and vigor scores also differed significantly between anthelmintic efficacy groups $(P=0.017)$ (Figure 8). Efficacy was independent from regrowth rate. This study was done on a short term, two rotations of grazing but long term grazing performance needs to be assessed. Accessions should be tolerant for more than one grazing period and overwinter. 
Reseeding should also be observed so that a low maintenance accession could be suggested. PI accessions were also identified with strong agronomic characteristics and efficacy; further research should be done to identify seed production possibilities and consistency of agronomic performance under long term rotational grazing.

Figure 7: Egg hatch inhibition groups showed a significant difference between plant survival rates. Error bars represent one standard error from the mean.

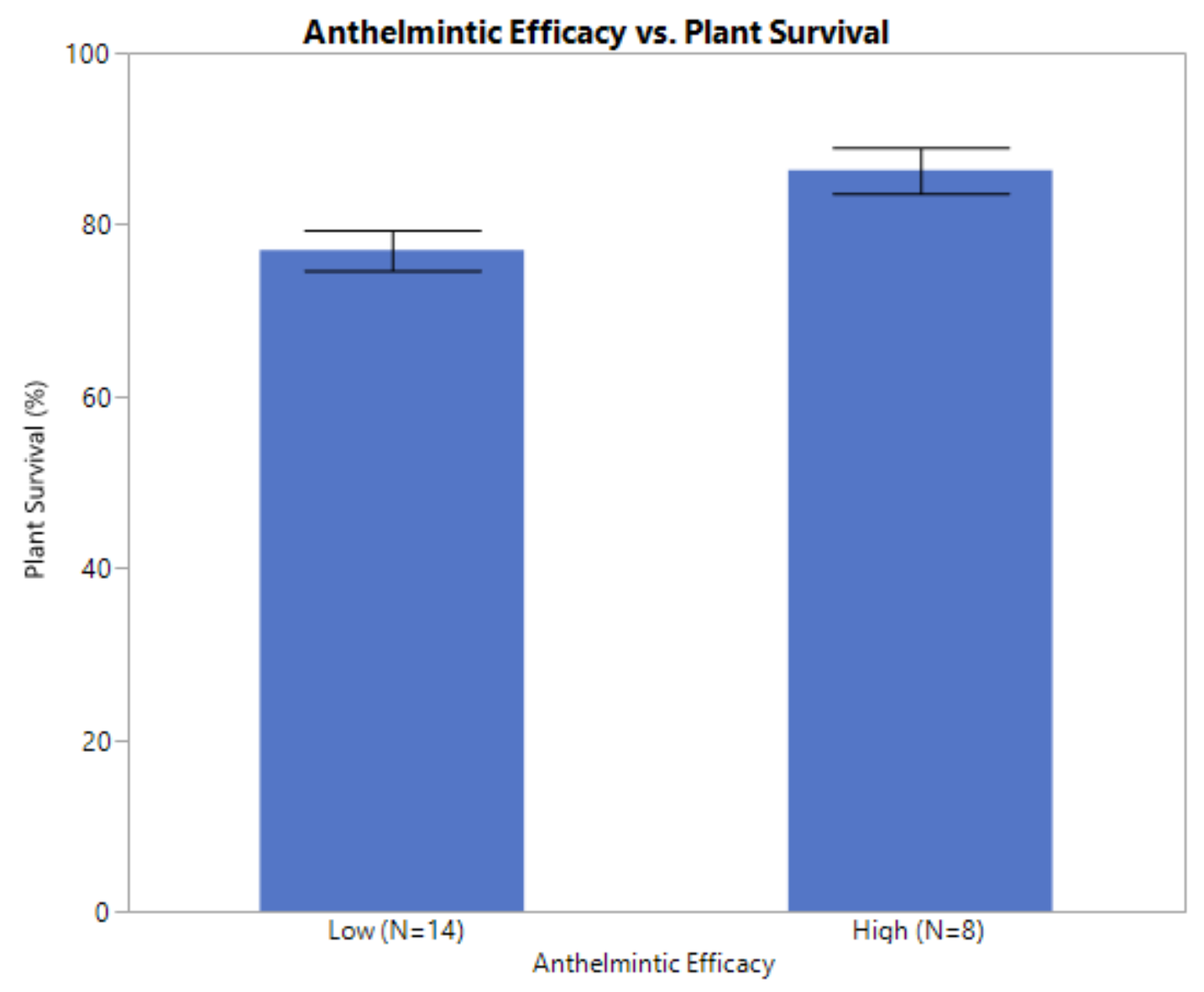


Figure 8: Anthelmintic efficacy showed a significant difference in groups between population quality scores. Error bars represent the standard error from the mean.

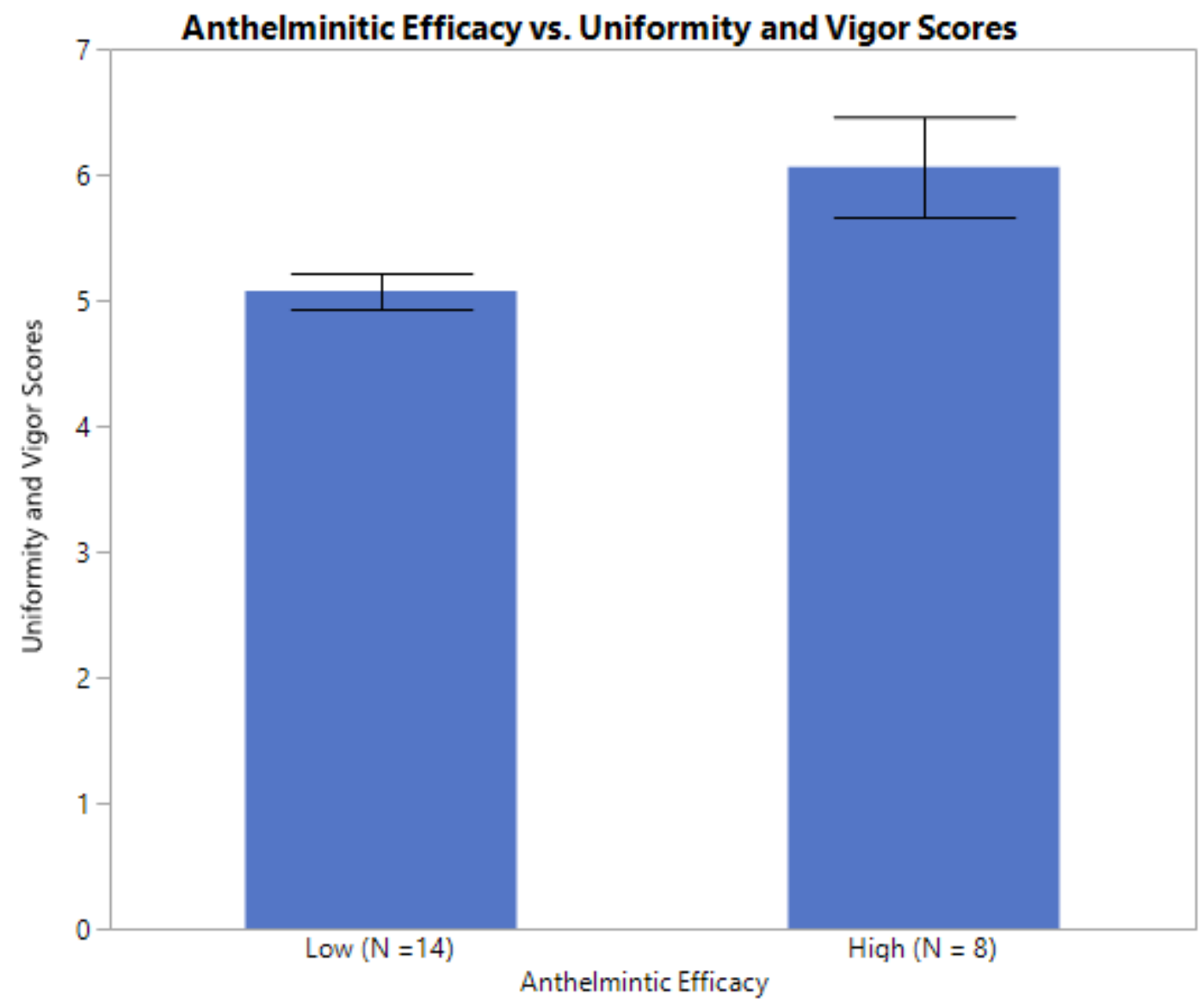




\section{Conclusion}

The 26 PI accessions and commercial cultivars of birdsfoot trefoil tested under rotational grazing differed in regrowth, grazing tolerance, and uniformity. The accessions and cultivars also differed in condensed tannin content and anthelmintic efficacy when tested in vitro. Tannin content did not affect plant survival or regrowth, suggesting that none of the accessions tested had sufficient tannin to be unpalatable to sheep. PI accessions and commercial cultivars were identified that show potential for use as medicinal pasture against $H$. contortus in the northeastern U.S. 'Empire' is well adapted to the Northeast, where it was selected from naturalized populations prior to 1955 Empire also scored high in anthelmintic efficacy. 'Empire' seed is currently available for producers. PI193725 also had high grazing tolerance and had a high efficacy against $H$. contortus. Seed production needs to be evaluated.

\section{References:}

Baumont, R. Prache, S. Meuret, M. Morand- Fehr, P. 2000. How forage characteristics influence behavior and intake in small ruminants: a review. Live Pro Sci. 64, $15-28$.

Elden, T. and McCaslin, M. 1997. Potato Leafhopper (Hamoptera:Ciedellidae) Resistance in Perennial Glandular-Haired Alfalfa Clones. J. Econ. Entomol. $90(3), 842-847$.

Emery, K. Beuselinck, P. English, J. 1999. Evaluation of the population dynamics of the forage legume Lotus corniculatus using matrix population models. New Phytol. 144, $549-560$. 
Fleming, S. Craig, T. Kaplan, R., Miller, J. Navarre, C. Rings, M. 2006. Anthelmintic Resistance of Gastrointestinal Parasites in Small Ruminants. J Vet Intern Med. $20,435-444$.

Grabber, J. Riday, H. Cassida, K. Griggs, T. Min, D. MacAdam, J. 2014. Yield, Morphological Characteristics, and Chemical Composition of European- and Mediterranean - Derived Birdsfoot Trefoil Cultivars Grown in the Colder Continental United States. Crop Sci. 54, 1893 - 1901.

Hale, M. 2006. Managing Internal Parasites in Sheep and Goats. ATTRA. 15 February 2014.

Hansen, J. Viands, D. Deubler, R. Crawford, J. Schiller, J. Crawford, R. 2012. New York Forage Legume and Grass Variety Yield Trial Summary for 2012 Season Totals. Cornell Univ.

Haring, D. Scharenberg, A. Heckendorn, F. Dohme, F. Luscher, A. Maurer, V. Suter, D. Hertzberg, H. 2008. Tanniferous forage plants: Agronomic performance, palatability and efficacy against parasitic nematodes in sheep. Renew Agr Food Syst. 23, $19-29$.

MacAdam, J. Brummer, J. Islam, A. Shewmaker, G. 2013. The Benefits of TanninContaining Forages. Utah State Univ.

MacAdam, J. and Griggs, T. 2006. Performance of birdsfoot trefoil, white clover, and other legume-grass mixtures under irrigation in the Intermountain West U.S.A. Proc. N.Z. Grassl. Assoc. 64, 355-359.

McGraw, R. Beuselinck, P. Marten, G. 1989. Agronomic and Forage Quality Attributes of Diverse Entries of Birdsfoot Trefoil. Crop Sci. 29, 1160 - 1164. 
Mechineni, A. Gujja, S. Kommuro, D. Mosjidis, J. Miller, J. Burke, J. Ramsay, A. Mueller-Harvey, I. Kannan, G. Lee, J. Kouakou, B. Terill, T. 2014. Effect of fall-grazed sericea lespedeza (Lespedeza cuneata) on gastrointestinal nematode infections of growing goats. Vet Parasitol. 204, 221-228.

Min, B. and Hart, S. 2003. Tannins for the suppression of internal parasites. J Anim Sci. 81, E102 - E109.

Molan, A. Waghorn, G. McNabb, C. 1999. Condensed tannins and gastro-intestinal parasites. Proc. NZ. Grass. Assoc. 61:57-61.

National Oceanic and Atmospheric Administration (NOAA). 2016. National Center for Environmental Information, U.S. Department of Commerce. 1 Nov 2016.

Ogle, D. John, L. Stannard, M. 2009. Species selection and grazing management guidelines. Technical Note. USDA Natural Resources Conservation Service.

Pecetti, L. Annicchiarico, P. Battini, F. Cappelli, S. 2009. Adaption of forage legume species and cultivars under grazing in two extensive livestock systems in Italy. Eur J Agron. 30, 199 - 204.

Roberts, C. Beuselinck, P. Ellersieck, M. Davis, D. McGraw, R. 1993. Quantification of Tannins in Birdsfoot Trefoil Germplasm. Crop Sci. 33, 675 - 679.

Seaney, R. and Henson, P. 1970. Birdsfoot trefoil. Adv Agron. 22, 119-157.

Schaller, F. Wedin, W. Carlson, I. 1997. Birdsfoot trefoil for pasture. Agronomy 2. Iowa State Univ.

Soil Survey Staff. 2015. Web soil survey. Natural Resources Conservation Service, U.S. Dept. Agr., 15 March 2016. 
Sollenberger, L. 2015. Challenges, Opportunities, and Applications of Grazing Research. Crop Sci. 55, 2540 - 2549.

Stiener, J. Beuselinck, P. Greene, S. Kamm, J. Kirkbirde, J. Roberts, C. 2001. A description and Interpretation of the NPGS Birdsfoot Trefoil Core Subset Collection. Crop Sci. 41, 1968 - 1980.

US Climate Data Staff. 2016. U.S. Climate Data.Your Weather Service. 15 March 2016.

USDA, 2014. Germplasm Resources Information Network (GRIN). 11 November 2014.

Undersander, D. Greub, L. Leep, R. Beuselinck, P. Wedberg, J. Smith, D. Kelling, K. Doll, J. Cosgrove, D. Grau, C. Peterson, S. Wipfli, M. English, J. 1993. Birdsfoot Trefoil for Grazing and Harvested Forage.

Waghorn, G. 2008. Beneficial and detrimental effects of dietary condensed tannins for sustainable sheep and goat production - Progress and challenges. Anim Feed Sci Tech. 147, $116-139$. 


\section{CHAPTER 5}

\section{CONCLUSION}

Birdsfoot trefoil (Lotus corniculatus L.) may be an effective medicinal forage for control of $H$. contorus in the northeastern U.S. Birdsfoot trefoil populations evaluated in this research showed positive agronomic characteristics and high levels of anthelmintic efficacy. Using tanniferous forage legumes can alleviate the economic loss in small ruminant farming due to gastrointestinal nematodes and decrease dependency on synthetic anthelmintics.

While the agronomic characteristics evaluated in this study showed varied results in vigor and uniformity, winter hardiness, growth habit, disease resistance, grazing tolerance and regrowth ability among the populations of BFT there were accessions and commercial cultivars that show promise as a forage in the Northeast. These agronomically viable accessions and cultivars also have promising anthelmintic efficacy.

This research supported Escaray et al. (2012) in that significant differences were seen between populations for winter hardiness and uniformity and vigor. Seaney and Hensen (1970) found that pest and disease would limit biomass of birdsfoot trefoil, resistant plants would not be affected. In 2013 and 2015 leafhopper damage did not correlate with uniformity and vigor or plant survival. Undersander et. al. (1993)

found that Empire type BFT had faster regrowth than European type birdsfoot trefoil. In this study, no correlation was seen between growth habit and regrowth. 
Future studies should focus on long term rotational grazing results, continuous grazing results and seed production ability of promising accessions. Currently available cultivars that performed well agronomically and had high anthelmintic efficacy includes, 'Empire', 'Leo', 'Bull', 'Pardee' and 'Norcen'. 


\section{APPENDICES}

\section{Appendix A}

Map of nursery. Randomized block design with three replications located at

University of Rhode Island's Greene H. Gardiner Crop Science Field Laboratory in

Kingston, RI.

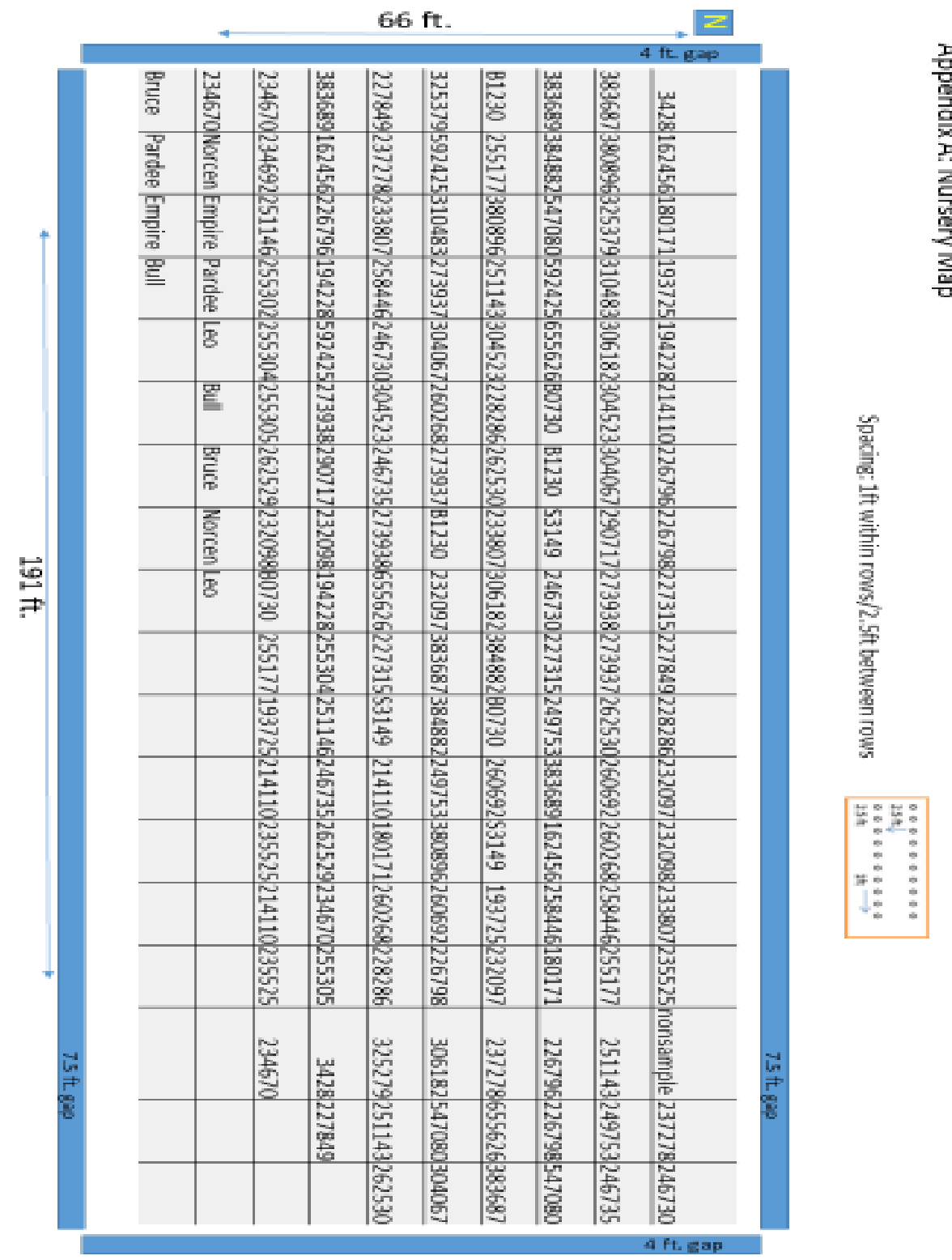


Map of Birdsfoot Trefoil grazing trial located at the University of Rhode Island's Peckham Farm in Kingston, RI.

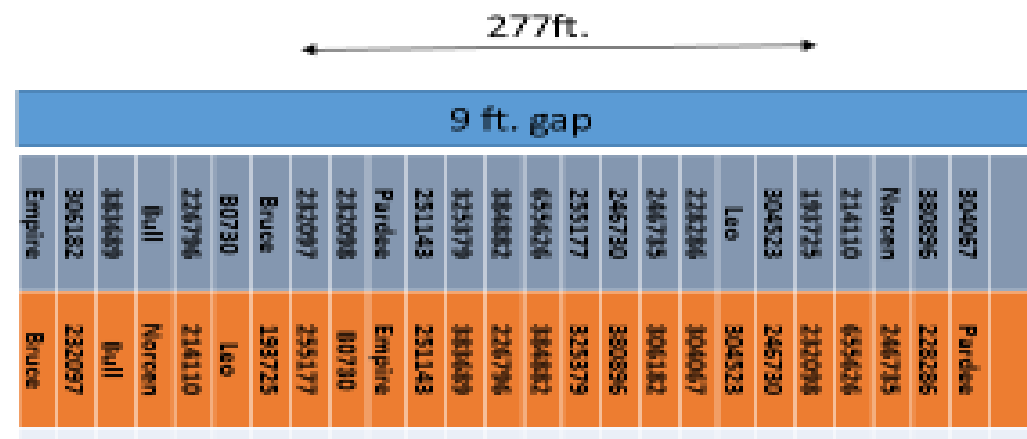

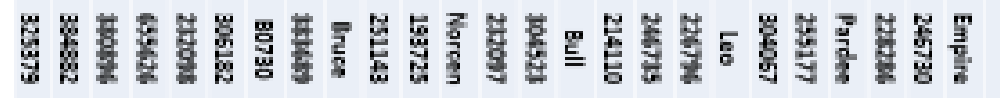

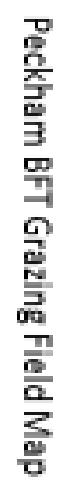

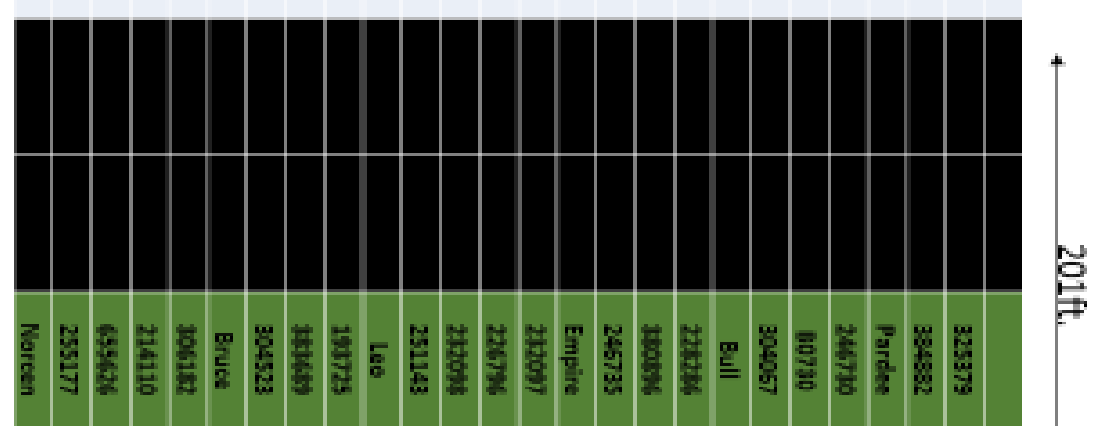

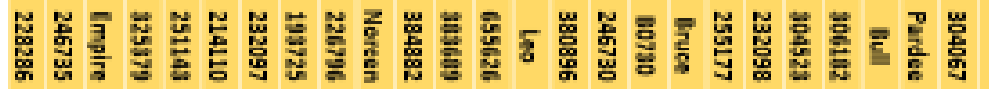

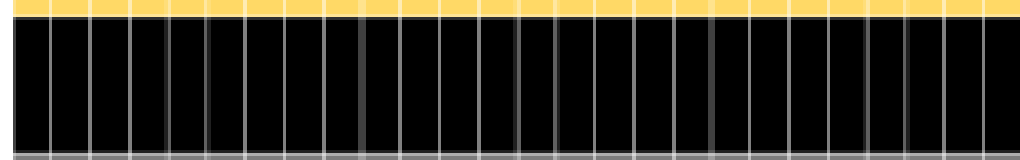

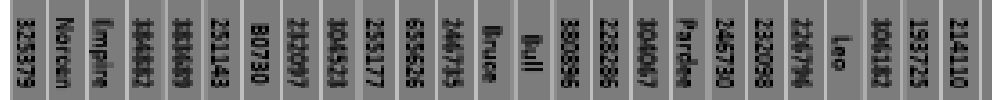

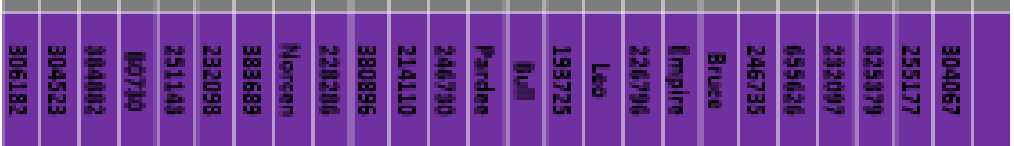

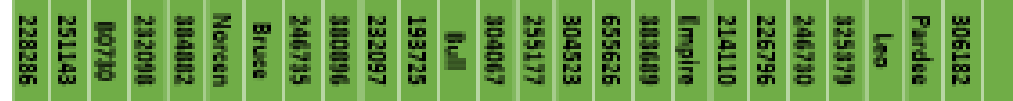
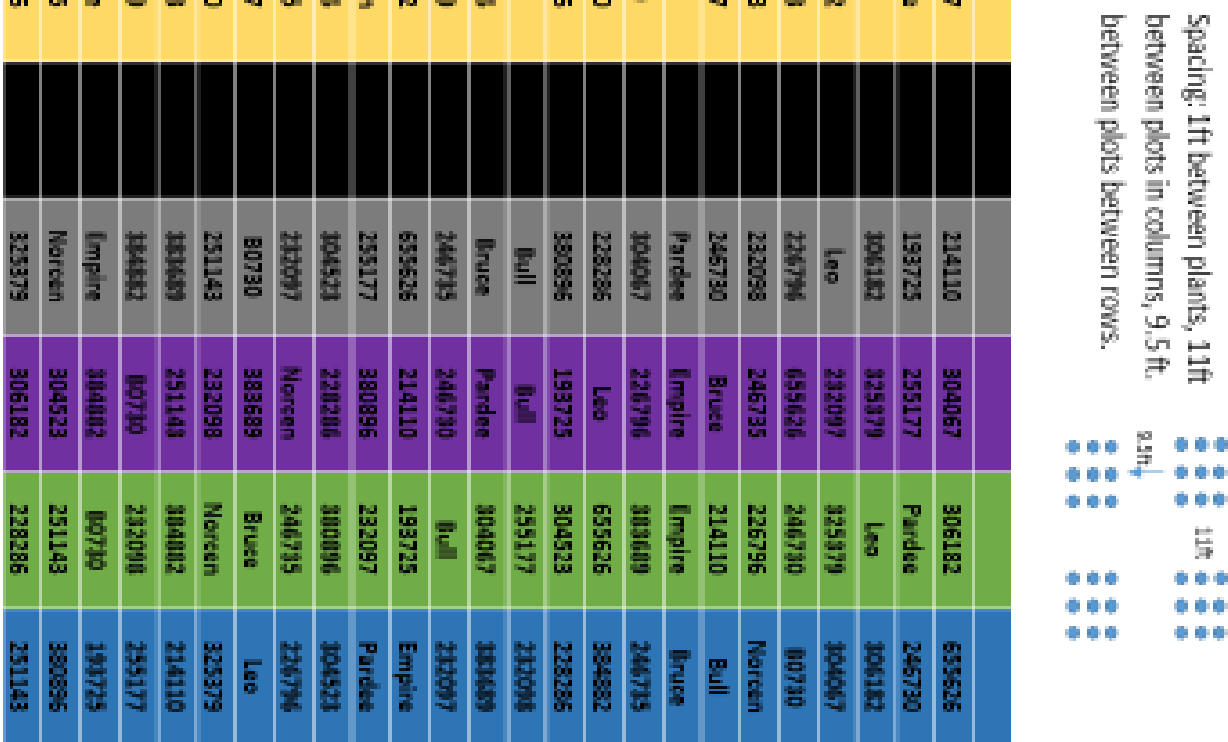

$$
\begin{aligned}
& \text { - 누요 } \\
& \text { - e. } \\
& \text { 咅 } \\
& \text { - e } \\
& \because \bullet \bullet
\end{aligned}
$$


Table 1: The 51 PI accessions and six commercial cultivars of BFT evaluated in field plantings from $2013-2015$.

\begin{tabular}{|c|c|c|c|}
\hline Accession & $\begin{array}{c}\text { Literature } T C T \\
\left(g * \mathrm{~kg}^{-1} * D M\right)^{1}\end{array}$ & $T y p e^{2}$ & Origin $^{1}$ \\
\hline 3428 & 24.6 & $\begin{array}{c}\mathrm{NC}-83 \mathrm{HT} \\
\text { breeding line }\end{array}$ & USA \\
\hline 162456 & 33 & Uncertain & Uruguay \\
\hline 180171 & 22 & Uncertain & Czech Republic \\
\hline 193725 & 25 & Uncertain & Sweden \\
\hline 194228 & 18 & Landrace & Croatia \\
\hline 214110 & 66 & Uncertain & Spain \\
\hline 226796 & 26 & Uncertain & Canada \\
\hline 226798 & 22 & Uncertain & Canada \\
\hline 227315 & 28 & $\begin{array}{c}\text { Cultivar Haute- } \\
\text { Vienne }\end{array}$ & France \\
\hline 227849 & 2 & Uncertain & Iran \\
\hline 228286 & 4 & Wild & Iran \\
\hline 232097 & 25 & $\begin{array}{c}\text { Cultivar } \\
\text { Oberdielbacher }\end{array}$ & Germany \\
\hline 232098 & 26 & $\begin{array}{c}\text { Cultivar } \\
\text { Oberhaunstadtler }\end{array}$ & Germany \\
\hline 233807 & 26 & Breeding line & Italy \\
\hline 234670 & group $2(17-33)$ & Cultivar Kalo & USA \\
\hline 234692 & 32 & Wild & Denmark \\
\hline 235525 & 65 & Wild & France \\
\hline 237278 & 23 & $\begin{array}{c}\text { Cultivar Late } \\
\text { Rosklilde II }\end{array}$ & Denmark \\
\hline 246730 & 68 & Wild & Spain \\
\hline 246735 & 69 & Wild & Spain \\
\hline 249753 & 53 & Wild & Greece \\
\hline 251143 & 17 & Wild & Macedonia \\
\hline 251146 & 17 & Landrace & Serbia \\
\hline 255177 & 22 & $\begin{array}{c}\text { Cultivar } \\
\text { Skrzeszowicka }\end{array}$ & Poland \\
\hline 255302 & 23 & $\begin{array}{l}\text { Cultivar Indre- } \\
\text { Moulins }\end{array}$ & France \\
\hline 255304 & 28 & Cultivar Sartha & France \\
\hline 255305 & 25 & Uncertain & Italy \\
\hline 258446 & 24 & $\begin{array}{c}\text { Cultivar Stripe } \\
13\end{array}$ & Italy \\
\hline 260692 & 9 & Uncertain & Italy \\
\hline 260268 & 94 & Uncertain & Ethiopia \\
\hline
\end{tabular}




\begin{tabular}{|c|c|c|c|}
\hline 262529 & 29 & $\begin{array}{l}\text { Cultivar } \\
\text { Trebicsky }\end{array}$ & Czech Republic \\
\hline 262530 & 30 & $\begin{array}{l}\text { Cultivar } \\
\text { Taborsky }\end{array}$ & Czech Republic \\
\hline 273937 & 98 & Wild & Ethiopia \\
\hline 273938 & 105 & Wild & Ethiopia \\
\hline 290717 & 23 & Uncertain & United Kingdom \\
\hline 304067 & 31 & Breeding line & Uruguay \\
\hline 304523 & 4 & Uncertain & Turkey \\
\hline 306182 & 11 & Cultivar Leo & USA \\
\hline 310483 & 19.4 & Cultivar Viking & USA \\
\hline 325379 & 6 & Uncertain & Ukraine \\
\hline 380896 & 6 & Wild & Iran \\
\hline 383687 & 4 & Wild & Turkey \\
\hline 383689 & 7 & Wild & Turkey \\
\hline 384882 & 4 & Wild & Iran \\
\hline 421026 & N/A & Cultivar Cascade & USA \\
\hline 547080 & 26 & $\begin{array}{c}\text { Cultivar AU } \\
\text { Dewey }\end{array}$ & USA \\
\hline 592425 & N/A & Cultivar MU 81 & USA \\
\hline 655626 & N/A & Cultivar Empire & USA \\
\hline B0730 & N/A & & USA \\
\hline B1230 & N/A & & USA \\
\hline S3149 & 24.3 & $\begin{array}{l}\text { Cultivar } \\
\text { Grasslands } \\
\text { Goldie }\end{array}$ & New Zealand \\
\hline Pardee & 20 & Cultivar & USA \\
\hline Norcen & 19.3 & Cultivar & USA \\
\hline Bruce & N/A & Cultivar & Canada \\
\hline Bull & N/A & Cultivar & Canada \\
\hline Empire & group 1 (2-9) & Cultivar & USA \\
\hline
\end{tabular}

Appendix B: ANOVA tables

Winter Survival 2014 ANOVA

\begin{tabular}{|l|l|l|l|l|l|}
\hline Source & DF & $\begin{array}{l}\text { Sum of } \\
\text { Squares }\end{array}$ & $\begin{array}{l}\text { Mean } \\
\text { Square }\end{array}$ & F value & Prob. $>$ F \\
\hline Accession & 49 & 3611.8537 & 73.7113 & 6.5840 & $<.0001$ \\
\hline Error & 81 & 906.8333 & 11.1955 & & \\
\hline C. Total & 130 & 4518.6870 & & & \\
\hline
\end{tabular}


Winter Survival 2015 ANOVA

\begin{tabular}{|l|l|l|l|l|l|}
\hline Source & DF & $\begin{array}{l}\text { Sum of } \\
\text { Squares }\end{array}$ & $\begin{array}{l}\text { Mean } \\
\text { Square }\end{array}$ & F value & Prob. $>$ F \\
\hline Accession & 56 & 3847.6067 & 68.7073 & 6.6514 & $<.0001$ \\
\hline Error & 93 & 960.6667 & 10.3297 & & \\
\hline C. Total & 149 & 4808.2733 & & & \\
\hline
\end{tabular}

Height/width ratio 2013 ANOVA

\begin{tabular}{|l|l|l|l|l|l|}
\hline Source & DF & $\begin{array}{l}\text { Sum of } \\
\text { Squares }\end{array}$ & $\begin{array}{l}\text { Mean } \\
\text { Square }\end{array}$ & F value & Prob. > F \\
\hline Accession & 49 & 30.522859 & 0.622915 & 5.0731 & $<.0001$ \\
\hline Error & 78 & 9.577507 & 0.122789 & & \\
\hline C. Total & 127 & 40.100366 & & & \\
\hline
\end{tabular}

Height/width ratio 2015 ANOVA

\begin{tabular}{|l|l|l|l|l|l|}
\hline Source & DF & $\begin{array}{l}\text { Sum of } \\
\text { Squares }\end{array}$ & $\begin{array}{l}\text { Mean } \\
\text { Square }\end{array}$ & F value & Prob. > F \\
\hline Accession & 55 & 7.824846 & 0.142270 & 1.5099 & 0.0399 \\
\hline Error & 93 & 8.762944 & 0.094225 & & \\
\hline C. Total & 148 & 16.587790 & & & \\
\hline
\end{tabular}

Nursery Quality Scores 2013 ANOVA

\begin{tabular}{|l|l|l|l|l|l|}
\hline Source & DF & $\begin{array}{l}\text { Sum of } \\
\text { Squares }\end{array}$ & $\begin{array}{l}\text { Mean } \\
\text { Square }\end{array}$ & F value & Prob. $>$ F \\
\hline Accession & 49 & 67.32564 & 1.37399 & 2.1275 & 0.0013 \\
\hline Error & 80 & 51.66667 & 0.64583 & & \\
\hline C. Total & 129 & 118.99231 & & & \\
\hline
\end{tabular}

Nursery Quality Scores 2014 ANOVA

\begin{tabular}{|l|l|l|l|l|l|}
\hline Source & DF & $\begin{array}{l}\text { Sum of } \\
\text { Squares }\end{array}$ & $\begin{array}{l}\text { Mean } \\
\text { Square }\end{array}$ & F value & Prob. $>$ F \\
\hline Accession & 47 & 123.69919 & 2.63190 & 3.9743 & $<.0001$ \\
\hline Error & 75 & 49.66667 & 0.66222 & & \\
\hline C. Total & 122 & 173.36585 & & & \\
\hline
\end{tabular}


Nursery Quality Scores 2015 ANOVA

\begin{tabular}{|l|l|l|l|l|l|}
\hline Source & DF & $\begin{array}{l}\text { Sum of } \\
\text { Squares }\end{array}$ & $\begin{array}{l}\text { Mean } \\
\text { Square }\end{array}$ & F value & Prob. > F \\
\hline Accession & 56 & 178.50000 & 3.18750 & 4.3066 & $<.0001$ \\
\hline Error & 93 & 68.83333 & 0.74014 & & \\
\hline C. Total & 149 & 247.33333 & & & \\
\hline
\end{tabular}

Potato Leaf Hopper damage 2013 ANOVA

\begin{tabular}{|l|l|l|l|l|l|}
\hline Source & DF & $\begin{array}{l}\text { Sum of } \\
\text { Squares }\end{array}$ & $\begin{array}{l}\text { Mean } \\
\text { Square }\end{array}$ & F value & Prob. > F \\
\hline Accession & 49 & 186.49231 & 3.80597 & 1.7449 & 0.0133 \\
\hline Error & 80 & 174.50000 & 2.18125 & & \\
\hline C. Total & 129 & 360.99231 & & & \\
\hline
\end{tabular}

Potato Leaf Hopper damage 2015 ANOVA

\begin{tabular}{|l|l|l|l|l|l|}
\hline Source & DF & $\begin{array}{l}\text { Sum of } \\
\text { Squares }\end{array}$ & $\begin{array}{l}\text { Mean } \\
\text { Square }\end{array}$ & F value & Prob. $>$ F \\
\hline Accession & 56 & 1238.6493 & 22.1187 & 4.1591 & $<.0001$ \\
\hline Error & 77 & 409.5000 & 5.3182 & & \\
\hline C. Total & 133 & 1648.1493 & & & \\
\hline
\end{tabular}

Grazing Trial Repeated Measures ANOVA

\begin{tabular}{|l|l|l|l|l|}
\hline Effect & Num DF & Den DF & F value & Prob. $>$ F \\
\hline Accession & 21 & 1163 & 0.084487 & $<.0001$ \\
\hline Grazing Event & 10 & 11630 & 32.277395 & $<.0001$ \\
\hline $\begin{array}{l}\text { Accession } x \\
\text { Grazing Event }\end{array}$ & 210 & 10490 & 2.4766 & $<.0001$ \\
\hline
\end{tabular}

Quality Scores before first grazing event ANOVA

\begin{tabular}{|l|l|l|l|l|l|}
\hline Source & DF & $\begin{array}{l}\text { Sum of } \\
\text { Squares }\end{array}$ & $\begin{array}{l}\text { Mean } \\
\text { Square }\end{array}$ & F value & Prob. > F \\
\hline Accession & 21 & 143.66882 & 6.84137 & 1.5599 & 0.0646 \\
\hline Error & 168 & 736.79960 & 4.38571 & & \\
\hline C. Total & 189 & 880.46842 & & & \\
\hline
\end{tabular}


Quality Scores before second grazing event ANOVA

\begin{tabular}{|l|l|l|l|l|l|}
\hline Source & DF & $\begin{array}{l}\text { Sum of } \\
\text { Squares }\end{array}$ & $\begin{array}{l}\text { Mean } \\
\text { Square }\end{array}$ & F value & Prob. > F \\
\hline Accession & 21 & 207.34788 & 9.87371 & 2.8684 & $<.0001$ \\
\hline Error & 167 & 574.85317 & 3.44223 & & \\
\hline C. Total & 188 & 782.20106 & & & \\
\hline
\end{tabular}




\section{BIBLIOGRAPHY}

Athanasiadou, S. Kyriazakis, I. Jackson, F. Coop, R., 2001. Direct anthelmintic effects of condensed tannins towards different gastrointestinal nematodes of sheep in vitro and in vivo studies. Vet. Parasitol. 99, 205-219.

Baumont, R. Prache, S. Meuret, M. Morand-Fehr, P. 2000. How forage characteristics influence behavior and intake in small ruminants: a review. Live Pro. Sci. 64, $15-28$.

Carlson, I. Elling, L.,Miller, D., \& Beuselinck, B. 1983. Norcen Birdsfoot Trefoil. North Central Regional Extension Publication.

Casler, M., Undersander, D., Fredericks, C., Combs, D., \& Reed, J. 2013. An On Farm Test of Perennial Forage Grass Varieties under Management Intensive Grazing. Journal of Production Agriculture. 11: 92 - 99.

Colvin, A. Walkden-Brown S., Knox, M. Scott, J. 2008. "Intensive rotational grazing assists control of gastrointestinal nematodosis of sheep in a cool temperate environment with summer-dominant rainfall”. Veterinary Parasitology. 153(12), pp. 08-20.

Davis, R. and Bell, D. 1957. A Comparison of Birdsfoot Trefoil-Bluegrass and Ladino clover-Bluegrass for Pasture:I. Response of Lambs. Agro. Journal. 8, 436 440.

Emery, K. Beuselinck, P. English, J. 1999. Evaluation of the population dynamics of the forage legume (Lotus corniculatus) using matrix population models. New Phytol. 144, $549-560$.

Elden, T. and McCaslin, M. 1997. Potato Leafhopper (Hamoptera:Ciedellidae) 
Resistance in Perennial Glandular-Haired Alfalfa Clones. J. Econ. Entomol. $90(3), 842-847$.

Escaray, F. Menendez, A. Garriz, A. Pieckenstain, F. Estrella, M. Castagno, L. Carrasco, P. Sanjuan, J. Ruiz, O. 2012. "Ecological and agronomic importance of the plant genus Lotus. Its application in grassland sustainability and the amelioration of constrained and contaminated soils," Plant Science. 182, pp. $121-133$.

Fleming, S. Craig, T. Kaplan, R., Miller, J. Navarre, C. Rings, M. 2006.

"Anthelmintic Resistance of Gastrointestinal Parasites in Small Ruminants,"Journal of Vetrinary Internal Medecine, 20, pp. 435-444.

Ford, J. and Barrett, B. (2011). Improving Red Clover Persistence under Grazing. Proceeding of the New Zealand Grasslands Association. 73: 119 - 124.

Frutos, P. Hervas, G. Geraldez, F. Mantecon, A. 2004. Review. Tannins and ruminant nutrition. Spanish Journal of Agricultural Research. 2, 191 - 202.

Grabber, J. Riday, H. Cassida, K. Griggs, T. Min, D. MacAdam, J. 2014. Yield, Morphological Characteristics, and Chemical Composition of European- and Mediterranean - Derived Birdsfoot Trefoil Cultivars Grown in the Colder Continental United States. Crop Sci. 54, pp. 1893 - 1901.

Grant, W. 2004. List of Lotus coniculatus (Birdsfoot trefoil). McGill University, Quebec, Canada.

Gujja, S., Terrill, T., Mosjidis, J., Miller, J., Michineni, A., Kommuru, D., Shaik, S., Lambert, B., Cherry, N., Burke, J. 2013. Effect of supplemental sericea 
lespedeza leaf meal pellets on gastrointestinal nematode infection in grazing goats. Veterinary Parasitology, 191(1-2): 51-58.

Hale, M. 2006. "Managing Internal Parasites in Sheep and Goats". ATTRA. 15 February 2014.

Hansen J. Viands, D. Deubler, R. Crawford, J. Schiller, J. Crawford, R. 2012. New York Forage and Grass Variety Yield Trial Summary for 2012 - Season Totals. Cornell Univ. Ithaca, NY.

Haring, D. Scharenberg, A. Heckendorn, F. Dohme, F. Luscher, A. Maurer, V. Suter, D. Hertzberg, H. 2008. “Tanniferous forage plants: Agronomic performance, palatability and efficacy against parasitic nematodes in sheep". Renewable Agriculture and Food Systems. 23, pp. $19-29$.

Jones, K. 2004. "Trends in the U.S. sheep industry." United States Department of Agriculture.

Leit - Browning, M. 2006. "Haemonchus contortus (barber pole worm) Infestation in Goats". Alabama A\&M and Auburn Universities, Alabama.

Lisonbee, L. 2008. Self-Medicative Behavior of Sheep Experiencing Gastrointestinal Nematode Infections and the Postingestive Effects of Tannins. Utah State University. Paper 168.

MacAdam, J. and Griggs, T. 2006. "Performance of birdsfoot trefoil, white clover, and other legume-grass mixtures under irrigation in the Intermountain West U.S.A.” Proceedings of the New Zealand Grassland Association, 64, pp. 355359. 
MacAdam, J. Brummer, J. Islam, A. Shewmaker, G. 2013. The Benefits of TanninContaining Forages. Utah State Univ.

Marley, C. Cook, R. Keatingge, R. Barrett, J. Lampkin, N. 2003. The effect of birdsfoot trefoil (Lotus corniculatus) and chicory (Cichorium intybus) on parasite intensities and performance of lambs naturally infected with helminth parasites. Vet. Parasitol. 112, $147-155$.

McGraw, R. Beuselinck, P. Marten, G. 1989. Agronomic and Forage Quality Attributes of Diverse Entries of Birdsfoot Trefoil. Crop Sci. 29, 1160 - 1164.

Mechineni, A. Gujja, S. Kommuro, D. Mosjidis, J. Miller, J. Burke, J. Ramsay, A. Mueller-Harvey, I. Kannan, G. Lee, J. Kouakou, B. Terill, T. 2014. Effect of fall-grazed sericea lespedeza (Lespedeza cuneata) on gastrointestinal nematode infections of growing goats. Vet Parasitol. 204, 221-228.

Miller-Garvin, J., Hansen, J., Ehlke, N., Papadopoulos, Y., Smith, R., Bergstrom, G., Wunsch, M., Kalb, D., Tillapaugh, B., Crawford, J., and Viands, D. 2011. Improving Birdsfoot Trefoil for Resistance to Fusarium Wilt. Crop Science, $51: 585-591$.

Min, B. and Hart, S. 2003. "Tannins for the suppression of internal parasites". Journal of Animal Science. 81, pp. E102 - E109.

Molan, A. Waghorn, G. McNabb, C. 1999. "Condensed tannins and gastro-intestinal parasites". Proceedings of the New Zealand Grassland Association. 61, pp. 5761.

Ogle, D. John, L. Stannard, M. 2009. Species selection and grazing management guidelines. Technical Note. USDA Natural Resources Conservation Service. 
Pecetti, L. Annicchiarico, P. Battini, F. Cappelli, S. 2009. Adaption of forage legume species and cultivars under grazing in two extensive livestock systems in Italy. Eur J Agron, 30, 199 - 204.

Roberts, C. Beuselinck, P. Ellersieck, M. Davis, D. McGraw, R. 1993. Quantification of Tannins in Birdsfoot Trefoil Germplasm. Crop Sci. 33, 675 - 679.

Santos, M. Silva, B. Amarante, A. 2012. "Environmental factors influencing the transmission of Haemonchus contortus". Veterinary Parasitology. 188(3-4), pp. $277-284$.

Saunders, Z. M., Jemigan, J, E. and Paulling, J. R. 1969. Trends in forage crops varieties-1969. United States Department of Agriculture Extension Service Publication.

Schaller, F. Wedin, W. Carlson, I. 1997. Birdsfoot trefoil for pasture. Agronomy 2. Iowa State University, Ames, Iowa

Seaney, R. and Henson, P. 1970. "Birdsfoot trefoil". Advanced Agronomy. 22, pp. $119-157$.

Soil Survey Staff. 2015. Web soil survey. Natural Resources Conservation Service, U.S. Dept. Agri. 15 March 2016.

Sollenberger, L. 2015. Challenges, Opportunities, and Applications of Grazing Research. Crop Sci. 55, pp. 2540 - 2549.

Stanton, T. 2012. "An overview of the Goat Meat Market". Cornell University, Ithaca, NY. 
Steiner, J., Beuselinck, P., Greene, S., Kamm, J., Kirkbride, J., \& Roberts, C. 2001. A Description and Interpretation of the NPGS Birdsfoot Trefoil Coore Subset Collection. Crop Science, 41: 1968-1980.

Undersander, D. Greub, L. Leep, R. Beuselinck, P. Wedberg, J. Smith, D. Kelling, K. Doll, J. Cosgrove, D. Grau, C. Peterson, S. Wipfli, M. English, J. 1993. Birdsfoot Trefoil for Grazing and Harvested Forage.

United States Climate Data Staff. 2016. U.S. Climate data. 15 March 2016.

United States Department of Agriculture (USDA), 2014. Germplasm Resources Information Network (GRIN). 11 November 2014.

Uzun, F., Beytullah, H., \& Ocak, D. 2015. Genetic potential of wild birdsfoot trefoil (Lotus corniculatus L.) seeds collected from different geographical locations regarding to nutrient composition and nutritive value. Agroforest System. 89: 963-972.

Viands, D. Miller-Garvin, J. Hansen, J. Neally, J. 2004. Registration of 'Pardee' Birdsfoot Trefoil. Crop Science. 44: 1488- 1491.

Waghorn, G.C., Douglas G.B., Niezen, J.H., McNabb, W.C. and Foote A.G. 1998. Forages with condensed tannins - their management and nutritive value for ruminants. Proceedings of the New Zealand Grassland Association. 60: 89-98.

Waghorn, G. 2008. Beneficial and detrimental effects of dietary condensed tannins for sustainable sheep and goat production - Progress and challenges. Ani. Feed Sci. Tech. 147, $116-139$. 
Wedin, W., Vetter, R., Scholl, J., \& Woods, W. 1967. An Evaluation of Birdsfoot Trefoil (Lotus corniculatus) in Pasture Improvement. Agronomy Journal. $59: 525-555$ 